\title{
SOEP
}

SOEPpapers

SOEPpapers

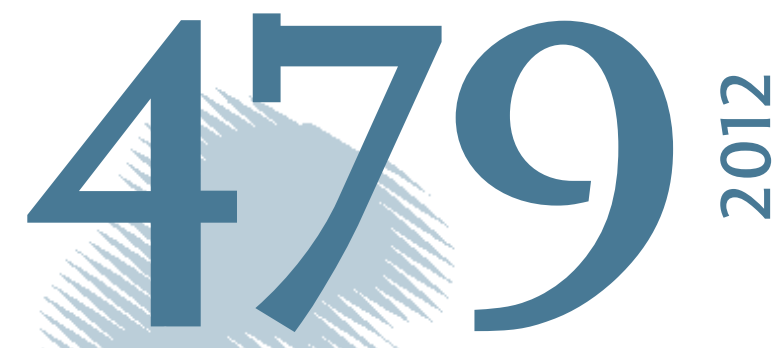

$\stackrel{N}{\sim}$

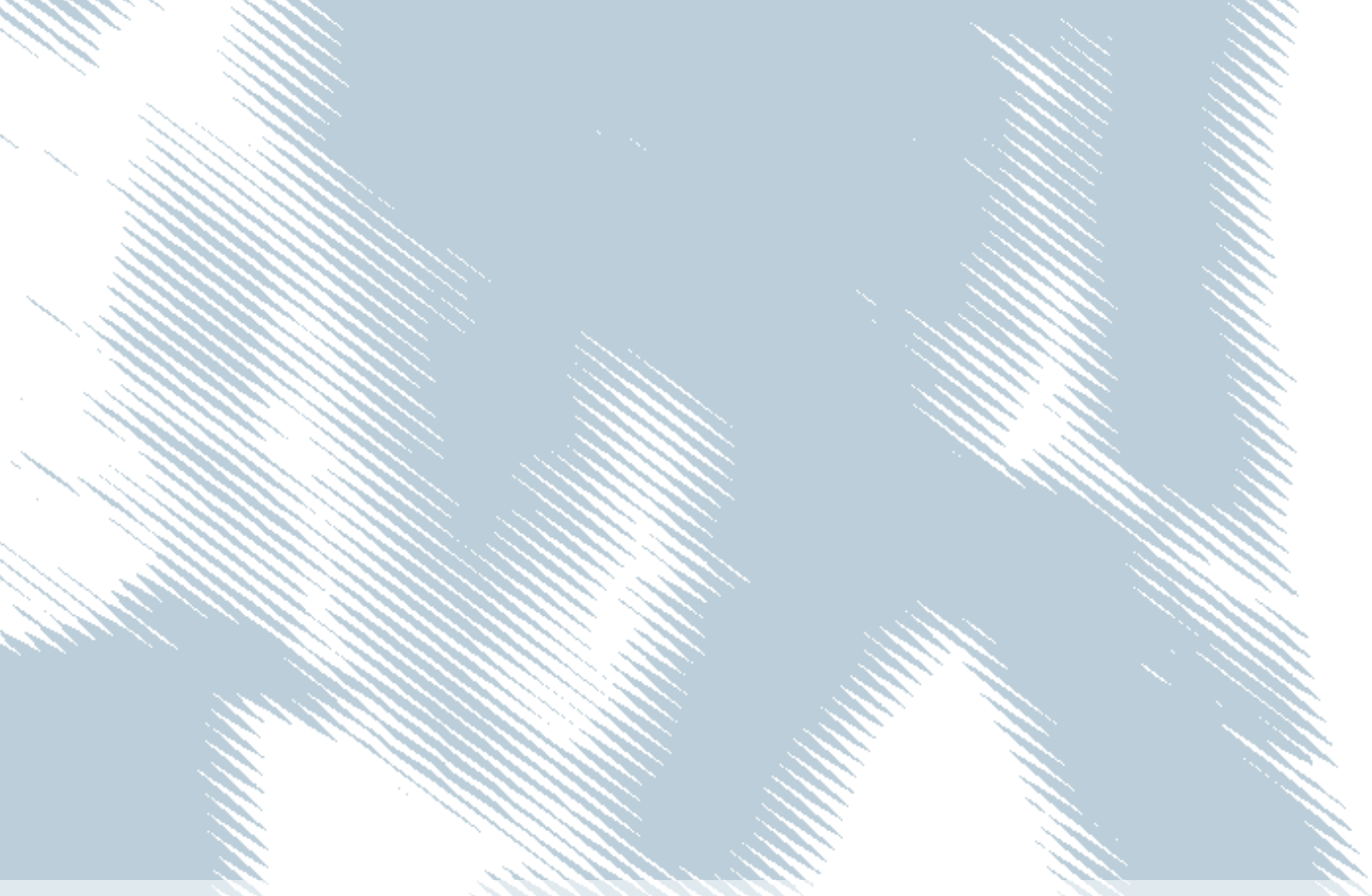

\section{Convergence or divergence? Immigrant wage assimilation patterns in Germany}




\section{SOEPpapers on Multidisciplinary Panel Data Research}

at DIW Berlin

This series presents research findings based either directly on data from the German SocioEconomic Panel Study (SOEP) or using SOEP data as part of an internationally comparable data set (e.g. CNEF, ECHP, LIS, LWS, CHER/PACO). SOEP is a truly multidisciplinary household panel study covering a wide range of social and behavioral sciences: economics, sociology, psychology, survey methodology, econometrics and applied statistics, educational science, political science, public health, behavioral genetics, demography, geography, and sport science.

The decision to publish a submission in SOEPpapers is made by a board of editors chosen by the DIW Berlin to represent the wide range of disciplines covered by SOEP. There is no external referee process and papers are either accepted or rejected without revision. Papers appear in this series as works in progress and may also appear elsewhere. They often represent preliminary studies and are circulated to encourage discussion. Citation of such a paper should account for its provisional character. A revised version may be requested from the author directly.

Any opinions expressed in this series are those of the author(s) and not those of DIW Berlin. Research disseminated by DIW Berlin may include views on public policy issues, but the institute itself takes no institutional policy positions.

The SOEPpapers are available at

http://www.diw.de/soeppapers

\section{Editors:}

Jürgen Schupp (Sociology, Vice Dean DIW Graduate Center)

Gert G. Wagner (Social Sciences)

Conchita D'Ambrosio (Public Economics)

Denis Gerstorf (Psychology, DIW Research Professor)

Elke Holst (Gender Studies)

Frauke Kreuter (Survey Methodology, DIW Research Professor)

Martin Kroh (Political Science and Survey Methodology)

Frieder R. Lang (Psychology, DIW Research Professor)

Henning Lohmann (Sociology, DIW Research Professor)

Jörg-Peter Schräpler (Survey Methodology, DIW Research Professor)

Thomas Siedler (Empirical Economics)

C. Katharina Spieß (Empirical Economics and Educational Science)

ISSN: 1864-6689 (online)

German Socio-Economic Panel Study (SOEP)

DIW Berlin

Mohrenstrasse 58

10117 Berlin, Germany

Contact: Uta Rahmann | soeppapers@diw.de 


\title{
Convergence or divergence?
}

\section{Immigrant wage assimilation patterns in Germany*}

\author{
Michael Zibrowius
}

August 2012

\begin{abstract}
Using a rich panel data set, I estimate wage assimilation patterns for immigrants in Germany as an example of a key European destination country. This study contributes to the literature by performing separate estimations by skill groups. Comparisons with similar natives reveal that immigrants' experience earnings profiles are flatter on average, although clear differences exist between skill groups. The effect of time spent in the host country is significantly positive and thus partly offsetting the diverging trend in the experience earnings profiles. Still, wage differences between natives and immigrants remain. They are particularly noticeable for highly skilled immigrants, the group needed most in Germany's skill intensive labor market.
\end{abstract}

JEL Codes: F22; J31; J61

Key Words: International migration; wage differentials; assimilation; longitudinal data

\section{Correspondence to:}

Michael Zibrowius

Economics Department

Univ. of Erlangen-Nuremberg

Lange Gasse 20

D-90403 Nuremberg

Germany

Email: michael.zibrowius@wiso.uni-erlangen.de

\footnotetext{
* Helpful comments by Regina T. Riphahn, Herbert Brücker, Barbara Hanel, David Kiss, Steffen Müller, Robert Orlowski, and Christoph Wunder on earlier versions of this paper are gratefully acknowledged. I wish to thank conference participants in Limerick, Nuremberg, Oslo, Ottawa, Paphos, Paris, and Perth for additional insights.
} 


\section{Introduction}

The assimilation of immigrants with respect to the social, cultural, and economic conditions in their host countries lies in the center of the debate of immigration policy in Europe. Kahanec and Zimmermann (2010) note that the "proper management of high-skilled immigration is of key importance for Europe,” and the OECD (2010a, 2010b) emphasizes the importance of policy reforms to close the prevalent employment gap especially in the highly skilled manufacturing sector. However, the question of whether their new host countries are in fact attractive for labor immigrants in the long run is open: what are the earnings opportunities of immigrants as compared to those of natives? Do immigrants catch up with natives given additional time spent in their new environment (as, e.g., Chiswick, 1978, finds for the United States) or do immigrants face persistent earnings disadvantages? Do they differ across skill groups, i.e., do highly skilled immigrants suffer greater wage penalties than low skilled immigrants as compared to their native counterparts? Moreover, do highly skilled immigrants face sufficiently dispersed returns to skills that make it attractive for them to come to Germany? The answers to these questions are particularly relevant in light of the ongoing global "Battle for Brains" (Bertoli et al., 2009) in which developed host countries with their highly skilled workforce is engaged.

I study how newly arrived immigrants to Germany, a major European destination country for labor migration, adjust to natives in terms of wages. I identify the effect of time spent in the host country on hourly wages, i.e., how years since migration influence the wage assimilation of immigrants. Furthermore, I look at how differences in returns to experience between natives and immigrants affect the assimilation process of immigrants. As attracting full time working immigrants is a political and economic objective, I restrict my analysis to the group of full time working first generation immigrants and examine whether they assimilate in terms of wages. 
Authors have investigated the assimilation of immigrants in Germany mainly on the basis of the German Socio-Economic Panel (SOEP) ${ }^{1}$ (see, among others, Aldashev et al., 2009; Constant and Massey, 2003, 2005; Schmidt, 1997; and Zeager, 1999). The results and methods used to obtain the effect of time spent in Germany (ysm) on wages vary considerably: while some researchers report no significant ysm-effect (Schmidt, 1997; Zeager, 1999), others find a concave effect as reported in Chiswick (1978) (see Aldashev et al., 2009) or even a slightly convex effect (as documented in Constant and Massey, 2003).

This study contributes to the literature by looking not only at immigrants and natives in general but by doing separate analyses for highly, medium, and low skilled workers. Additionally and in contrast to previous work that omits important variables (such as occupational and industry information) or does not control for age at migration (Chiswick and Miller, 2003; Adsera and Chiswick, 2007), I control for an extensive array of socio-economic background information. Furthermore, allowing for differences in the effect of additional work experience between immigrants and natives yields less biased results for the measured effect of years since migration.

I present evidence that the assimilation pattern as measured by the effect of time spent in the host country is generally statistically significant in Germany. Nevertheless, substantial differences in the extent of wage convergence between immigrants and natives exist over the course of their working lives, especially with respect to their skill level. These differences are partly driven by disparities in the returns to experience. At low values of work experience, additional work experience yields lower returns for immigrants than for natives. Yet, after 19 years of work experience, returns to additional experience are higher for immigrants than for natives. However, by that time the earnings gap has already widened too far, such that wage convergence can no longer be achieved. Results also differ by skill groups: immigrants are

\footnotetext{
${ }^{1}$ For a detailed description of the dataset, refer to SOEP (2010) or Wagner et al. (2007).
} 
able to catch up with their native counterparts if they are low skilled and they face diverging wages if they are highly skilled.

\section{Theoretical background}

Theoretical explanations for wage differences between immigrants and natives as well as the subsequent convergence or divergence of wage levels for both groups are. I present three main conceptual approaches and derive their implications for the earnings path of immigrants over time relative to that of natives.

The most widely used departure point in dealing with differences in earnings is human capital theory (Becker, 1975; Mincer, 1974). Existing inequalities in earnings are traced back to differences in skills, which in turn lead to differences in productivity and thus different wages. Immigrants who arrive in their new host country often lack country-specific human capital—such as information about customs and traditions, or information about labor market institutions - irrespective of whether or not their formal educational qualification is the same as that of natives. The lack of these country-specific skills may lead to lower starting wages of immigrants as compared to natives. By upgrading their level of skills, i.e., by investments in their human capital, immigrants should be able to increase their productivity and catch up with natives, ceteris paribus. Thus, we assume that the time spent in the host country used for investing in host country-specific skills has a positive effect on immigrants' wages. The effect of years since migration could therefore be positive, given such investments in host countryspecific human capital occur.

To account for an initial earnings gap between immigrants and natives, we can also refer to theories of discrimination. According to Becker (1957), discrimination arises when members of one group (e.g., immigrants) are treated differently (i.e., are paid less or are less likely to be promoted) than the members of a different group (e.g., natives), even though both 
groups dispose of the same observable characteristics. An earnings gap may arise because of statistical discrimination or stereotypical thinking of employers, or because of pure preference-based discrimination (cf. Arrow, 1973; Brekke and Mastekaasa, 2008; and Quillian, 2006, among others). Discrimination in the form of lower wages for immigrants may also be rational for employers, if immigrants' reservation wages are below those of natives when faced with the same job offer. The relevance of discrimination may even increase over immigrants’ working careers since job promotion usually goes along with higher earnings. As work experience increases, the earnings differential between immigrants and natives may be widening if "glass ceilings" prevent immigrants to reach certain positions and the earnings associated with them (cf. Cotter et al., 2001; Pendakur and Woodcock, 2010).

The idea of increasing inequalities between immigrants and natives regarding their wages is likewise employed in the theory of cumulative advantages, dating back to Merton (1968). Tomaskovic-Devey et al. (2005) and Brekke and Mastekaasa (2008) adopt this theory for human capital acquisition and immigration. If the production of human capital is at least in part endogenously determined by the kind of an individual's job or work, then those employees with a "good" first job that offers sufficient possibilities for training and learning will also have a higher probability of obtaining a better second job afterwards; a good second job will lead to a good third job; and so on. If immigrants have in general a worse starting position than natives (e.g., because they lack country-specific human capital or are discriminated against) they (i) will have lower observed returns to experience and (ii) may not be able to catch up with natives even if the returns to years since migration are positive.

These three theoretical approaches used to explain the path of earnings convergence or divergence between immigrants and natives are by no means exhaustive. Their predictions are partly ambiguous and unobserved aspects play an important role. In the remainder, however, I 
concentrate on testing the following hypotheses to find answers to the three questions stated in the first Section.

Hypothesis 1: A positive effect of years since migration on earnings is expected for additional country-specific human capital given that immigrants start acquiring such host country-specific human capital once they arrive. I thus expect immigrants to catch up with natives in terms of earnings with additional years since migration.

Hypothesis 2: As natives may be able to move up the career ladder faster than immigrants, the returns to work experience are expected to be ceteris paribus higher for natives than for immigrants with otherwise comparable characteristics. I therefore expect the experience earnings profiles of immigrants to be flatter than those of natives, and a divergence of wages between immigrants and natives.

Hypothesis 3: Differences in the effect of work experience between immigrants and natives are expected to be more pronounced in case of highly skilled as compared to low skilled individuals. The productivity of highly skilled individuals is more closely tied to their level of experience, as they are typically employed in more complex working environments (see Constant and Massey (2005)). For highly skilled immigrants, the "glass ceiling” effect should thus be of greater importance. The cumulative advantages of natives may lead to greater discrepancies in the returns to experience than is the case for the low skilled, especially during the early years of the working career. I therefore assume the difference in the returns to experience to be the largest for highly skilled and the smallest for low skilled individuals. 


\section{Data and method}

\subsection{Data, sample, and descriptive statistics}

I use data from the 1984 to 2009 waves of the German Socio-Economic Panel (SOEP). The SOEP is a nationally representative longitudinal survey covering approximately 11,000 households and more than 20,000 individuals. In contrast to administrative data, it offers not only gross earnings and work related information, but also a wide variety of socio-economic and family background variables. Since immigrants are oversampled, the data contain a sufficiently large number of observations. I consider first generation immigrants, defined as those immigrants born outside of Germany with an own migration experience. Natives are made up of individuals born in Germany and having German citizenship since birth. Second generation immigrants are thus not included in the analysis. ${ }^{2}$

The sample contains male, full time workers aged 18-65 for whom information is available about the dependent variable, i.e., the logarithm of gross hourly earnings (in 2006 prices), and all other background variables. ${ }^{3}$ Military personnel (ISCO code 0) are excluded from the analysis. As only few immigrants live and work in East Germany I only use individuals residing in West Germany. ${ }^{4}$ To exclude potential outliers the top and bottom one percent of observations with respect to hourly wages are dropped. ${ }^{5}$ After these adjustments the sample consists of 56,991 person-year observations for natives and 16,810 for immigrants based on 8,160 and 2,444 individuals, respectively.

For both immigrants and natives the analysis further separates by skill group that I define referring to the International Standard Classification of Education (ISCED). A person

\footnotetext{
${ }^{2}$ I drop those individuals who (i) are born in Germany and do not have German citizenship or who (ii) are born in Germany and acquired German citizenship only later in their lives. As more than 60 percent of all respondents have missing values for their parent's nationality, I restrain myself to this distinction.

${ }^{3}$ The situation of immigrant women is not considered. The sample restrictions applied would lead to an insufficient number of observations in the respective cells because of low full time work participation of women.

${ }^{4}$ Only 1.85 percent of all migrants sampled in the SOEP reside in East Germany.

${ }^{5}$ This was done separately for immigrants and natives to account for differences in the earnings distributions of both groups.
} 
is considered as low skilled if he has completed only primary or lower secondary education (ISCED 1-2). Individuals are referred to as medium skilled if they have achieved some sort of upper secondary schooling and/or post-secondary, non tertiary education such as vocational training ${ }^{6}$ (ISCED 3-4). In the German educational system, this group includes individuals whose highest educational degree is the Abitur. Highly skilled individuals are those who have received advanced vocational training or attained a tertiary educational degree from college or university (ISCED 5-6).

Table 1 presents summary statistics for natives (columns I-IV) and immigrants (columns V-VIII). In the pooled samples for natives and immigrants (columns I and V), outcomes are similar for many variables such as actual work experience or age. However, we find clear differences in average gross hourly wages (in 2006 Euros), where the wages of immigrants are 21 percent below those of natives (not adjusted for differences in skills). However, the skill distributions of immigrants and natives differ substantially: while only 10 percent of the immigrants are highly skilled and 40 percent have no secondary educational degree, these numbers are almost reversed in case of the natives, where 33 percent are highly skilled and only 12 percent are in the low skill category.

\section{Table 1 about here}

I find sizeable differences in the distributions of natives and immigrants with respect to occupations and sectors (cf. Table 1). Because of these inequalities, outcomes are also regarded separately for the main professional groups (see Section 5).

\footnotetext{
${ }^{6}$ ISCED level 4 programs are designed to prepare students for studies at ISCED level 5 who, although having completed ISCED level 3 (upper secondary education), did not follow a curriculum that would allow direct entry to level 5. Typical examples are pre-degree foundation courses or short vocational programs (technical schools, evening courses etc.).
} 
The observed immigrant-native differences in average characteristics are similar within skill groups. Highly skilled immigrants have the largest wage gap with a 19 percent disadvantage.

Table 2 sheds light on immigrant specific individual characteristics. Most immigrants have already spent a considerable amount of time in Germany (the median is 19 years, the average value 19.4 years) and a majority of them, especially the predominantly low skilled guest workers (Gastarbeiter) arrived in Germany before 1973. We observe large shares of immigrants from the typical recruitment countries for guest workers (Pischke and Velling, 1997), namely, Turkey, Greece, Italy, and former Yugoslavia. Highly skilled immigrants, most of whom arrived in Germany after 1973, have to a larger extent Eastern European roots or come from other Western countries. 50 percent of the highly skilled immigrants are German citizens, whereas this is the case for only 7 percent of the low skilled.

Table 2 about here

\subsection{Empirical Method}

Chiswick (1978) as well as Borjas (1985) consider U.S. census data and use standard OLS estimators to identify the ysm effect. Regarding the European case, this has also been the most prominent approach (see, e.g., Zimmermann, 2005, for an overview of existing evidence). For this analysis I also turn to OLS and use clustered standard errors to allow for individual error term correlation. ${ }^{7}$ As endogeneity is of concern when estimating earnings equations including measures of experience and tenure, the estimated coefficients should be regarded as describing correlations rather than distinct causal effects. Return migration, which

\footnotetext{
${ }^{7}$ While applying panel estimation approaches such as random (RE) or fixed effects (FE) leads to slightly different point estimates, the results are qualitatively similar to those of OLS. However, FE does not allow for the identification of the coefficients of time invariant covariates such as country of origin or arrival cohort. In addition, results for nearly time invariant covariates such as occupations, sectors, but also language skills rely on very few changers. Note that a RE specification failed the Hausman test of uncorrelatedness of the covariates and the individual-specific error term. Using OLS also allows comparisons with the existing literature, e.g. Adsera and Chiswick (2007).
} 
may lead to positive selection in the group of immigrants staying in Germany (because of non-random panel attrition), might be a further issue. Yet, also using data from the SOEP, Dustmann and van Soest (2002) as well as Constant and Massey (2003) show that no such effect is observable. ${ }^{8}$

An important issue when dealing with earnings equations is to disentangle the perfectly multicollinear period, cohort, and time effects. Controlling for arrival cohorts, years since migration, and calendar year dummies would lead to unidentifiable coefficients. I circumvent this problem by using a very broad definition of immigration cohorts (i.e., I distinguish only between immigrants having arrived prior to 1973, between 1974 and 1988, and after 1989) as well as following the suggestion of Heckman and Robb (1985) to use the average yearly (West German) unemployment rate instead of calendar year dummies as a proxy for general business cycle effects.

Years since migration and actual work experience are both significantly positively correlated with the logarithmized hourly wage of immigrants. Given a likewise significant positive correlation between these two variables ${ }^{9}$, omitting either experience or ysm in the regression equation would lead to a distinct upward bias in the estimated effect of the included variable. Wald tests for models using only ysm, only experience, or both variables as third degree polynomials for immigrants (in addition to the vectors of socio-demographic control variables, see below) reveal significant differences in the estimated correlation patterns of these variables. ${ }^{10}$ Hence, both ysm and experience are included jointly.

Novel in the German assimilation literature, I let the entire effect of experience differ between immigrants and natives. By not imposing that German experience affects both

\footnotetext{
${ }^{8}$ They note, however, that in case of the existence of selective return migration, the estimated effects of language fluency and other variables should be considered as lower bounds of the real effects.

${ }^{9}$ For immigrants, the correlation coefficient between work experience and log(hourly wage) is .16, between ysm and $\log$ (hourly wage) .29, and between work experience and ysm .47.

${ }^{10}$ Wald tests allow for testing cross-model hypotheses, e.g., regarding significant differences in the effect of particular variables in two or more different model specifications, which is what is done here.
} 
groups to the same extent, I can further reduce the potential bias in the effect of both experience and ysm explained before: now, the experience effect for natives is no longer swayed by the biased estimates of the immigrant experience effect. ${ }^{11}$

Following McDonald and Worswick (1998) the framework for the analysis is a standard wage model of the following form:

$$
\log \left(\text { hourly_wage }_{i t}\right)=\alpha_{1 n} \text { exper }_{i t}+\alpha_{2 n} \text { exper }_{i t}{ }^{2}+\alpha_{3 n} \operatorname{exper}_{i t^{3}}+\beta_{n}{ }^{\prime} X_{i t}+\theta_{n} u r_{t}+\varepsilon_{i t}
$$

for natives, and

$$
\begin{gathered}
\log \left(\text { hourly_wage }_{i t}\right)=\alpha_{1 m} \text { exper }_{i t}+\alpha_{2 m} \text { exper }_{i t}{ }^{2}+\alpha_{3 m} \text { exper }_{i t}{ }^{3}+\beta_{m}{ }^{\prime} X_{i t}+\theta_{m} u r_{t} \\
+\gamma_{1 m} y_{s m_{i t}}+\gamma_{2 m} y s m_{i t}^{2}+\gamma_{3 m} y s m_{i t}^{3}+\delta_{m}{ }^{\prime} Z_{i t}+\varepsilon_{i t}
\end{gathered}
$$

for immigrants.

To facilitate inference, the two equations are jointly estimated in a fully interacted model. ${ }^{12}$ The dependent variable is the logarithm of gross hourly wages in 2006 prices. Experience (exper) is measured by an individual's actual work experience instead of some measure of potential work experience. $X$ represents a vector of individual characteristics such as tenure in linear, quadratic, and cubic form; number of children in the household; dummy variables for region of residence, community size, marital status, self-employment, occupation and sector; and a constant. $Z$ includes immigrant specific information in terms of

\footnotetext{
${ }^{11}$ Note that assimilation rates of immigrants may also differ with respect to the expected length of stay in the host country. Immigrants wishing to stay only temporarily may be less inclined to invest in country specific human capital than those who wish to spend the rest of their lives in the host country, which may affect both wages in general as well as the returns to ysm of both groups to a different extent. While information about the intended duration of stay is asked in the survey, the non-response rate is unfortunately above 60 percent. I thus refrain from further differentiating immigrants according to this variable in the following analysis. Estimations using immigrants with an expected length of stay of less than five years vs. more than five years do not yield different results (not presented here).

${ }^{12}$ Results from models using only squared terms of experience, tenure and ysm do not differ qualitatively from the models presented here and are available from the author upon request. As the cubic terms are all jointly significant, they are included to improve explanatory power (cf. Murphy and Welsh, 1990). Additionally, they allow for modeling the marginal effects of work experience and ysm as $2^{\text {nd }}$ degree polynomials instead of imposing the same slope over the entire range.
} 
language skill indicators (spoken and written ${ }^{13}$ ), arrival cohort, age at migration, and country of origin. $\theta_{n}$ and $\theta_{m}$ measure the effect of the average yearly unemployment rate for West Germany $(u r)^{14} \cdot \varepsilon_{i}$ stands for an idiosyncratic error term. Subscripts $n$ and $m$ refer to natives and immigrants, where immigrant coefficients refer to the interaction term between an immigrant-dummy and the corresponding variable. Models omitting regional information and not controlling for industry and occupation, as well as models excluding immigrant specific characteristics were estimated separately to verify the robustness of the results. An overview is given in Appendix Table A1. For all further analyses, I choose the previously presented model incorporating all available information, because of the highest explanatory power in terms of the adjusted $\mathrm{R}^{2}{ }^{15}$

\section{Results and discussion}

In this section I examine how individual characteristics affect hourly wages and test whether immigrants' earnings converge to those of natives with additional time spent in the host country. I consider how differences in hourly wages evolve over time by looking at the effects of additional work experience and years since migration to test hypotheses 1-3.

Appendix Tables A2-A5 give a full summary of the OLS results for the pooled and the skill-group samples. Table 3 presents the estimation results for the coefficients of experience and ysm of the full sample. Duration of residence in Germany is clearly correlated with hourly wages: while the ysm terms are all individually insignificant, they are highly significant when tested jointly. The result confirms human capital theory, i.e., country-

\footnotetext{
${ }^{13}$ Language skill is self-assessed and asked every second year. I impute the missing years by (i) the value of both previous and subsequent year when no change occurred and (ii) the value of the previous year if a change occurred. If the first observation is missing, I use the available information of the subsequent year.

${ }^{14}$ The unemployment rate was obtained from official tables of the German Federal Employment Agency, see http://statistik.arbeitsagentur.de/Navigation/Statistik/Statistik-nach-Themen/Zeitreihen/zu-den-ProduktenNav.html (last retrieved August 2012).

${ }^{15}$ Models including "schooling in Germany" or "degree from German school" are insignificant as long as language is controlled for. Therefore, these controls are not included as the effects of the other variables of interest (ysm, experience) do not change significantly.
} 
specific human capital acquired in the years after migration is positively associated with earnings (see Figure 1). Furthermore, the coefficients of German language proficiency (spoken and written) are both positive and significant (see Appendix Table A2). Nonetheless, other factors apart from language proficiency (attributable, e.g., to getting accustomed to the host country's labor market institutions and working culture) appear to have a significant positive effect on earnings. The effect of years since migration captures the acquisition of this host country-specific human capital. As it is jointly significant and positive for all values from 0 to 37, hypothesis 1 cannot be rejected.

\section{Table 3, Figure 1 about here}

For natives, an additional year of experience (measured at the mean of experience) is associated with an increase in hourly wages by ceteris paribus .24 percent, whereas the comparable effect for immigrants is .22 percent. The result suggests that there is hardly any difference between the two groups when considering the returns to experience. However, when looking at the predicted experience earnings profiles (Figure 2) of immigrants and natives, ${ }^{16}$ we see considerably lower earnings of immigrants at low values of work experience, i.e., at the beginning of their careers. Moreover, we can infer from Figure 3 that the effect of work experience is greater for natives: holding ysm for immigrants constant, at a level of work experience of one year an additional year of work experience is associated with an increase of hourly wages for natives by 3.1 percent as compared to an increase of 2.1 percent for immigrants. At 5 years of experience, the effect is 2.2 percent for natives and 1.5 percent for immigrants. Immigrants receive the same returns to an additional year of work experience only after they have already reached 19 years of work experience (see Figure 3). By that time, the average differences in the hourly wage rates are already considerable. Even

\footnotetext{
${ }^{16}$ The experience earnings profiles were calculated by setting the variables of immigrants and natives at their respective means and varying experience, holding constant tenure and ysm. This was done using STATA's adjust command.
} 
though Figure 3 provides some evidence for converging wages at higher values of experience (i.e., higher returns to experience for immigrants than for natives), the initial divergence cannot be fully overcome. However, when looking at the combined effect of additional years of work experience going along with additional time spent in Germany (see Figure 3), results change. In this case, where all of an immigrant's work experience is obtained in Germany, equality in the effect of experience is already reached after 10 years. Still, the results deliver overall evidence in favor of hypothesis 2, i.e., higher initial wage growth for natives with additional work experience (cf. Figures 2 and 3). ${ }^{17}$

Figures 2 and 3 about here

As the observations described previously refer to the average outcome of all persons and differences in skills are controlled for only by changes in the intercept, I present separate estimations for highly, medium, and low skilled workers to test hypothesis 3 . Table 4 offers selected results for the different skill groups.

When considering the effect of ysm on hourly wages for immigrants, we observe positive marginal effects for all skill groups (that is, between 5 and 30 years of residence), although the ysm terms are jointly significant only for medium and low skilled immigrants (see Table 4, Figure 4). Still, these results appear to confirm hypothesis 1.

\section{Table 4, Figure 4 about here}

Hypothesis 2, which suggests higher wage growth for natives with additional work experience, is also not rejected. Ceteris paribus, immigrants reach parity in the marginal effect of additional work experience after 13 (medium skilled) to 27 (high skilled) years, when natives have already reached higher hourly wages than their immigrant peers (not shown to save space). In general, immigrants’ predicted experience earnings profiles are flatter than

\footnotetext{
${ }^{17}$ The p-value for the F-test of joint significance of the experience-immigrant interactions is .00.
} 
those of natives (see Figures A1, A3, and A5 in the appendix). Again, combining the marginal effect of experience and ysm for immigrants leads to earlier intersects of the curves depicting the returns to experience for immigrants and natives (cf. Tables A2, A4, and A6 in the appendix). Here, we even observe that wages grow at a stronger rate for immigrants than for natives for the low skilled at all levels of experience.

Having investigated the skill groups separately we can now test whether the difference in the returns to experience is the largest for the highly skilled and the smallest for the low skilled. I compare the differences in the returns to experience between immigrants and natives. I find significant differences in the marginal effects of work experience after 1 and 5 years of experience between the high skill and low skill subgroups, whereas the differences between the high and medium skill subgroups are only significant after 5 years. ${ }^{18}$ Overall, I interpret the finding as strong evidence in favor of hypothesis 3: low skilled immigrants profit from additional work experience to the same extent than natives, but highly skilled natives have significantly higher returns to experience than immigrants (at least at low levels of experience). The finding for the high skill group seems reflect a considerable head start for natives as predicted by the theory of cumulative advantages.

As a last point, I compare the predicted experience earnings profiles for highly, medium, and low skilled immigrants (referring to the estimation results from Table 4). If sufficient dispersion in the returns to skills exists between the groups, highly skilled immigrants will consider Germany an attractive host country and, eventually, move there (cf. Borjas, 1999). ${ }^{19}$ Figure 5 shows that highly skilled immigrants fare considerably better than their peers with lower skills. Further information about the returns to skills in the respective

\footnotetext{
${ }^{18}$ Bearing in mind the relatively small sample size of high skilled immigrants, which may account for high standard errors, insignificant differences in some cases should not be surprising. The p-value for the test of difference in the returns after 1 year is .07 and thereby not too far off the 5 percent threshold.

${ }^{19}$ Borjas argues that host countries are more attractive for highly skilled immigrants the higher the wage dispersion in the host country as compared to the home country. In Germany, the average wage premium for highly skilled immigrants with respect to their medium (low) skilled peers is 29 (37) percent.
} 
home countries of immigrants would be needed to identify from which countries high skilled migration is most likely to occur. Still, the result shows that a considerable dispersion in the returns to skill in Germany exists, making it in general more likely and more worthwhile for highly skilled individuals to immigrate there.

Figure 5 about here

\section{Results for different immigrant subgroups}

To test whether the results obtained earlier hold in different contexts, I repeat the estimations for selected immigrant subgroups. Specifically, I consider immigrants who arrived in Germany before vs. after 1973 (the time of the first oil price shock that marks the end of Germany's active guest worker recruitment), as well as those entering Germany after the collapse of the Socialist Regime in Eastern Europe after 1989 (as they reflect the increasing share of immigrants from Eastern European countries, cf. Table 2). I also look separately at immigrants younger than vs. older than 18 years at the time of arrival in Germany (as the latter group was presumably not exposed to the German educational system). Detailed results are available from the author upon request.

Considering these subgroups, I find only small differences compared with the full sample. Years since migration enter the estimations significantly in all cases, a result that holds also when skill groups are considered separately (except for highly skilled immigrants). Similar results are valid for the experience interactions, where I find significant differences in the effect of work experience in all subgroups (although not in all skill groups). The general picture of flatter predicted experience earnings profiles for natives also holds for all subgroups. Only in isolated cases their profiles are steeper (low skilled individuals having arrived after 1989) or even flatter (immigrants having arrived in Germany at age 18 or above). 
Since the distribution of immigrants and natives across industries differs, I also consider possible differences in the effects of ysm and experience by industries (cf. Table 1). The estimated coefficients of the ysm polynomial are jointly significant in manufacturing and construction. Significant differences immigrants and natives in the effect of experience are observed in manufacturing and in public administration and services. Even though the effect of ysm and additional work experience is not significant in all industries, the predicted experience earnings profiles confirm the general findings obtained before. In particular, they show the steeper experience earnings profiles for natives compared to immigrants at low values of experience. Note that it is the industries with the greatest differences in terms of the share of immigrants and natives working there that show significant differences in the estimated effects. In industries where this share is relatively similar (cf. Table 1), the differences are generally insignificant. However, the latter industries also tend to be smaller, such that the lack of significance may simply be a result of a small number of observations in these industries.

\section{Conclusion}

Using a novel empirical approach to identify wage assimilation of immigrants in Germany, we observe several remarkable features based on the results from the analyses carried out in this work.

First, the time immigrants spend in their new host country is indeed significantly and positively correlated with their wages. This result confirms classic human capital theory, which suggests that immigrants acquire host country-specific human capital over time. Taken by itself, the result of a-ceteris paribus—-positive correlation of years since migration with hourly wages might be considered as evidence for wage assimilation, i.e., a catching-up of immigrant earnings compared to natives. Second, compared to average natives, immigrants 
earn lower hourly wages at all levels of experience. Especially for low values of work experience, natives receive higher returns for additional experience. Even when the marginal effects of experience and years since migration are combined, immigrants are only able to reach the wage level of natives in the low (and partly the medium) skill group. Third, as the difference in the returns to additional work experience is the greatest for highly skilled immigrants, issues such as cumulative advantages of natives, along with possible discrimination with respect to employment opportunities and earnings (glass ceilings) appear to be particularly relevant for this group. It remains for further research to quantify precisely how early employment prospects affect immigrants’ labor market outcomes differently from those of natives.

Summarizing the results I find that except for the low skilled, immigrants in Germany are generally not able to catch up with comparable natives with respect to wages. Even when the returns to additional work experience are higher for immigrants (especially when combined with the positive effect of years since migration) than for natives at high values of work experience, the initial divergence cannot be entirely overcome except in case of the low skilled immigrants. Especially for highly skilled immigrants, i.e., those immigrants needed to close the employment gap in Germany's knowledge society, the long term prospects are rather discouraging. The earnings gap between them and their native counterparts is not decreasing over the course of their professional careers-a fact that may repel potential immigrants when they look for a permanent new home and hope for full assimilation and immigration even given that their appears to be sufficient dispersion in the returns to skills among immigrants.

Even though the presented evidence rests upon retrospective data and may thus suffer from the "problem of induction" (Hume, 1740), assuming that the general observations are valid and remain so in the future should be of great concern for policy makers. If Germany is 
to adapt a policy of focusing on highly skilled immigrants as currently discussed in the political debate, extensive efforts need to be made by politicians as well as employers not to discourage these highly skilled immigrants direly needed at the German labor market. Future research should also center on the question to what extent differences in bargaining power drive the observed results, as a wider availability of outside options or different job offers might strengthen natives' (wage) bargaining power relative to immigrants—especially in high skilled occupations.

\section{Reference}

Adsera, A., Chiswick, B. R., 2007. Are there gender and country of origin differences in immigrant labor market outcomes across European destinations? Journal of Population Economics 20 (3), 495-526.

Aldashev, A., Gernandt, J., Thomsen, S. L., 2009. Language usage, participation, employment and earnings: Evidence for foreigners in West Germany with multiple sources of selection. Labour Economics 16 (3), 330-341.

Arrow, K. J., 1973. The Theory of Discrimination. In: Ashenfelter, O., Rees, A. (Eds.), Discrimination in Labor Markets. Princeton University Press, Princeton, 3-33.

Becker, G. S., 1957. The economics of discrimination, 2nd Edition, University of Chicago Press, Chicago IL.

Becker, G. S., 1975. Human Capital: A Theoretical and Empirical Analysis, with Special Reference to Education, 2nd Edition, Columbia University Press, New York.

Bertoli, S., Brücker, H., Facchini, G., Mayda, A. M., Peri, G., 2009. The Battle for Brains: How to Attract Talent. Report presented at the Fondazione Rodolfo de Benedetti, XI European Conference on "Brain drain and brain gain", Pisa.

Borjas, G. J., 1985. Assimilation, Changes in Cohort Quality, and the Earnings of Immigrants. Journal of Labor Economics 3 (4), 463-489.

Borjas, G. J., 1999. The Economic Analysis of Immigration. In: Ashenfelter, O., Card, D., (Eds.), Handbook of Labor Economics, Vol. 3A, Elsevier, Amsterdam, 1697-1760.

Brekke, I., Mastekaasa, A., 2008. Highly educated immigrants in the Norwegian labour market: permanent disadvantage? Work, employment and society 22 (3), 507-526. 
Chiswick, B. R., 1978. The Effect of Americanization on the Earnings of Foreign-born Men. Journal of Political Economy 86 (5), 897-921.

Chiswick, B. R., Miller, P. W., 2003. The complementary of language and other human capital: immigrant earnings in Canada. Economics of Education Review 22 (5), 469-480.

Constant, A., Massey, D. S., 2003. Self-selection, earnings, and out-migration: A longitudinal study of immigrants to Germany. Journal of Population Economics 16 (4), 631-653.

Constant, A., Massey, D.S., 2005. Labor Market Segmentation and the Earnings of German Guestworkers. Population Research and Policy Review 24 (5), 489-512.

Cotter, D. A., Hermsen, J. M., Ovadia, S., Wanneman, R., 2001. The Glass Ceiling Effect. Social Forces 80 (2), 655-681.

Dustmann, C., van Soest, A., 2002, Language and the earnings of immigrants. Industrial and Labor Relations Review 55 (3), 473-492.

Heckman, J. J., Robb, R., 1985. Using Longitudinal Data to Estimate Age, Period and Cohort Effects in Earnings Equations. In: Mason, W. M., Fienberg, S. E. (Eds.), Cohort Analysis in Social Research, Springer, New York, 137-150.

Hume, D., 1740. A Treatise of Human Nature: Being an Attempt to introduce the experimental Method of Reasoning into Moral Subjects. Printed for John Loon, London.

Kahanec, M., Zimmermann, K. F., 2011. High-Skilled Immigration Policy in Europe. In: Chiswick, B. R. (Ed.), High Skilled Immigration in a Global Labor Market, The AEI Press, Washington, D.C., 264-314.

McDonald, J. T., Worswick, C., 1998. The earnings of immigrant men in Canada: job tenure, cohort, and macroeconomic conditions. Industrial and Labor Relations Review 51 (3), 465482.

Merton, R. K., 1973. The Matthew Effect in Science. In: Storer, N.W. (Ed.), The Sociology of Science, University of Chicago Press, Chicago IL, 439-459.

Mincer, J., 1974. Schooling, experiences, and earnings. National Bureau of Economic Research, New York.

Murphy, K. M., Welsh, F., 1990. Empirical Age-Earnings Profiles. Journal of Labor Economics 8 (2), 202-229.

OECD, 2010a. OECD Economic Outlook 2010(2). Paris and Washington, D.C., Organisation for Economic Co-operation and Development.

OECD, 2010b. OECD International Migration Outlook: SOPEMI 2010. Paris and Washington, D.C., Organisation for Economic Co-operation and Development.

Pendakur, K., Woodcock, S., 2010. Glass Ceilings or Glass Doors? Wage Disparity Within and Between Firms. Journal of Business \& Economic Statistics 28 (1), 181-189. 
Pischke, J.-S., Velling, J., 1997. Employment Effects of Immigration to Germany: An Analysis Based on Local Labor Markets. Review of Economics and Statistics 79 (4), 594-604.

Quillian, L., 2006. New Approaches to Understanding Racial Prejudice and Discrimination. Annual Review of Sociology 32 (1), 299-328.

Schmidt, C. M., 1997. Immigrant Performance in Germany: Labor Earnings of Ethnic German Migrants and Foreign Guest-Workers. Quarterly Review of Economics and Finance 37 (1) (Special Issue), 379-397.

SOEP, 2010. Data for years 1984-2009, version 26, SOEP (Socio-Economic Panel), doi:10.5684/soep.v26.

Tomaskovic-Devey, D., Thomas, M., Johnson, K., 2005. Race and the Accumulation of Human Capital Across the Career: A Theoretical Model and Fixed Effects Application. American Journal of Sociology 111 (1), 58-89.

Wagner, G. G., Frick, J. R., Schupp, J., 2007. The German Socio-Economic Panel Study (SOEP) - Evolution, Scope and Enhancements. Schmollers Jahrbuch (Journal of Applied Social Science Studies) 127 (1), 139-169.

Zeager, L. A., 1999. Earnings Growth for Foreign Guest Workers and West Germans: CrossSection and Panel Estimates. Vierteljahrshefte zur Wirtschaftsforschung 68 (2), 308-312.

Zimmermann, K. F. (ed.), 2005. European Migration: What Do We Know? Oxford University Press, Oxford. 


\section{Tables}

Table 1: Descriptive statistics - personal and residential background, occupations and industries, means

\begin{tabular}{|c|c|c|c|c|c|c|c|c|}
\hline & \multicolumn{4}{|c|}{ Natives } & \multicolumn{4}{|c|}{ Immigrants } \\
\hline & All & High & Medium & Low & All & High & Medium & Low \\
\hline Variable & I & II & III & IV & $\mathrm{V}$ & VI & VII & VIII \\
\hline \multicolumn{9}{|l|}{ Personal characteristics } \\
\hline Hourly wage (2006 Euros) & 16.65 & 20.93 & 14.79 & 13.49 & 13.26 & 16.95 & 13.18 & 12.41 \\
\hline Age & 41.14 & 43.47 & 40.08 & 39.60 & 40.94 & 43.17 & 39.89 & 41.68 \\
\hline Tenure in years & 12.73 & 12.59 & 12.34 & 14.78 & 10.46 & 9.66 & 9.67 & 11.65 \\
\hline Experience in years & 18.71 & 18.11 & 18.96 & 19.19 & 19.68 & 18.07 & 18.53 & 21.52 \\
\hline Actual weekly hours & 44.98 & 46.65 & 44.36 & 43.24 & 42.11 & 44.96 & 42.14 & 41.34 \\
\hline $\begin{array}{l}\text { Self-employed (=1 if person is } \\
\text { selfemployed, =0 otherwise) }\end{array}$ & 0.08 & 0.11 & 0.07 & 0.03 & 0.03 & 0.08 & 0.03 & 0.02 \\
\hline Number of children in household & 0.75 & 0.85 & 0.71 & 0.66 & 1.16 & 1.00 & 1.14 & 1.23 \\
\hline $\begin{array}{l}\text { Married (=1 if person is married, =0 } \\
\text { otherwise) }\end{array}$ & 0.70 & 0.77 & 0.67 & 0.63 & 0.83 & 0.86 & 0.82 & 0.83 \\
\hline \multicolumn{9}{|l|}{ Residential information } \\
\hline South Germany & 0.47 & 0.48 & 0.47 & 0.43 & 0.54 & 0.53 & 0.54 & 0.56 \\
\hline Central Germany & 0.35 & 0.34 & 0.35 & 0.39 & 0.34 & 0.33 & 0.34 & 0.34 \\
\hline North Germany & 0.18 & 0.18 & 0.18 & 0.18 & 0.12 & 0.14 & 0.13 & 0.10 \\
\hline Community $<20,000$ inhabitants & 0.16 & 0.12 & 0.18 & 0.16 & 0.06 & 0.05 & 0.07 & 0.05 \\
\hline Community 20,000-100,000 inhabitants & 0.56 & 0.56 & 0.57 & 0.56 & 0.58 & 0.52 & 0.56 & 0.62 \\
\hline Community $>100,000$ inhabitants & 0.28 & 0.32 & 0.25 & 0.28 & 0.36 & 0.43 & 0.37 & 0.33 \\
\hline \multicolumn{9}{|l|}{ Level of qualification } \\
\hline High-skilled (ISCED 5 - 6) & 0.33 & & & & 0.10 & & & \\
\hline Medium-skilled (ISCED 3 - 4) & 0.55 & & & & 0.50 & & & \\
\hline Low-skilled (ISCED 1 - 2) & 0.12 & & & & 0.40 & & & \\
\hline \multicolumn{9}{|l|}{ Occupational classification by ISCO88 } \\
\hline ISCO1 - Legislators, senior officials and & 0.08 & 0.13 & 0.06 & 0.03 & 0.02 & 0.05 & 0.02 & 0.02 \\
\hline ISCO2 - Professionals & 0.20 & 0.49 & 0.04 & 0.09 & 0.04 & 0.32 & 0.01 & 0.00 \\
\hline $\begin{array}{l}\text { ISCO3 - Technicians and associate } \\
\text { professionals }\end{array}$ & 0.19 & 0.20 & 0.19 & 0.14 & 0.05 & 0.14 & 0.05 & 0.03 \\
\hline ISCO4 - Clerks & 0.09 & 0.03 & 0.11 & 0.10 & 0.03 & 0.05 & 0.04 & 0.03 \\
\hline $\begin{array}{l}\text { ISCO5 - Service workers and shop and } \\
\text { market sales worker }\end{array}$ & 0.04 & 0.01 & 0.04 & 0.12 & 0.02 & 0.01 & 0.02 & 0.01 \\
\hline $\begin{array}{l}\text { ISCO6 - Skilled agricultural and fishery } \\
\text { workers }\end{array}$ & 0.01 & 0.01 & 0.01 & 0.01 & 0.01 & 0.01 & 0.01 & 0.01 \\
\hline ISCO7 - Craft and related trades workers & 0.24 & 0.10 & 0.34 & 0.20 & 0.40 & 0.19 & 0.48 & 0.34 \\
\hline $\begin{array}{l}\text { ISCO8 - Plant and machine operators and } \\
\text { assmblers }\end{array}$ & 0.10 & 0.02 & 0.13 & 0.20 & 0.27 & 0.13 & 0.24 & 0.33 \\
\hline ISCO9 - Elementary occupations & 0.04 & 0.01 & 0.05 & 0.09 & 0.13 & 0.07 & 0.10 & 0.19 \\
\hline ISCO N.A. & 0.02 & 0.02 & 0.03 & 0.02 & 0.04 & 0.02 & 0.03 & 0.04 \\
\hline \multicolumn{9}{|l|}{ Industry } \\
\hline Agriculture / Fishery & 0.01 & 0.01 & 0.01 & 0.02 & 0.01 & 0.01 & 0.01 & 0.01 \\
\hline Manufactoring & 0.36 & 0.33 & 0.39 & 0.28 & 0.58 & 0.49 & 0.57 & 0.63 \\
\hline Construction & 0.10 & 0.06 & 0.12 & 0.10 & 0.13 & 0.07 & 0.15 & 0.12 \\
\hline Trade, transportation, communication & 0.15 & 0.07 & 0.19 & 0.19 & 0.11 & 0.10 & 0.12 & 0.09 \\
\hline $\begin{array}{l}\text { Credit institutions, housing, } \\
\text { business-related services }\end{array}$ & 0.11 & 0.15 & 0.10 & 0.04 & 0.03 & 0.11 & 0.02 & 0.01 \\
\hline Public administration / services & 0.21 & 0.32 & 0.11 & 0.30 & 0.05 & 0.17 & 0.03 & 0.03 \\
\hline Miscellaneous & 0.03 & 0.02 & 0.04 & 0.03 & 0.04 & 0.02 & 0.04 & 0.04 \\
\hline N.A. & 0.04 & 0.03 & 0.04 & 0.04 & 0.06 & 0.04 & 0.05 & 0.07 \\
\hline Number of persons & 8,456 & 2,982 & 4,989 & 1,210 & 2,444 & 314 & 1,270 & 1,037 \\
\hline Number of observations & 58,611 & 19,326 & 32,045 & 7,240 & 16,810 & 1,712 & 8,381 & 6,717 \\
\hline
\end{tabular}

Source: SOEP, years 1984-2009. 
Table 2: Descriptive statistics - immigrant background, means

\begin{tabular}{|c|c|c|c|c|}
\hline & & \multicolumn{3}{|c|}{ Qualification } \\
\hline & All & High & Medium & Low \\
\hline \multicolumn{5}{|c|}{ Immigrant-specific characteristics } \\
\hline Years since migration (YSM) & 19.44 & 19.99 & 18.95 & 19.91 \\
\hline \multicolumn{5}{|l|}{ Immigration cohort } \\
\hline pre 1973 & 0.57 & 0.37 & 0.51 & 0.71 \\
\hline $1974-1988$ & 0.25 & 0.31 & 0.26 & 0.21 \\
\hline 1989 - & 0.18 & 0.32 & 0.23 & 0.08 \\
\hline Age at migration & 21.50 & 23.17 & 20.94 & 21.77 \\
\hline \multicolumn{5}{|l|}{ Language skills } \\
\hline Spoken German (very) good & 0.49 & 0.48 & 0.53 & 0.44 \\
\hline Spoken German missing & 0.15 & 0.37 & 0.19 & 0.05 \\
\hline Written German (very) good & 0.29 & 0.42 & 0.33 & 0.20 \\
\hline Written German missing & 0.15 & 0.37 & 0.19 & 0.05 \\
\hline German citizenship & 0.22 & 0.50 & 0.30 & 0.07 \\
\hline \multicolumn{5}{|l|}{ Country of origin } \\
\hline Turkey & 0.28 & 0.15 & 0.25 & 0.35 \\
\hline Former Yugoslavia & 0.15 & 0.09 & 0.18 & 0.14 \\
\hline Greece & 0.09 & 0.07 & 0.06 & 0.14 \\
\hline Italy & 0.16 & 0.04 & 0.13 & 0.22 \\
\hline Spain / Portugal & 0.08 & 0.05 & 0.07 & 0.10 \\
\hline Other Western & 0.04 & 0.13 & 0.04 & 0.01 \\
\hline Eastern European & 0.14 & 0.29 & 0.20 & 0.03 \\
\hline Asia & 0.05 & 0.08 & 0.07 & 0.02 \\
\hline Other & 0.02 & 0.10 & 0.02 & 0.00 \\
\hline Number of persons & 2,444 & 314 & 1,270 & 1,037 \\
\hline Number of observations & 16,810 & 1,712 & 8,381 & 6,717 \\
\hline
\end{tabular}

Source: SOEP, years 1984-2009. 
Table 3: Estimation results, all skill groups

\begin{tabular}{|c|c|c|c|c|c|c|}
\hline & \multicolumn{3}{|c|}{ Natives } & \multicolumn{3}{|c|}{ Immigrant Interactions } \\
\hline & Coefficient & & $\begin{array}{c}\text { Standard } \\
\text { error }\end{array}$ & Coefficient & & $\begin{array}{c}\text { Standard } \\
\text { error }\end{array}$ \\
\hline Experience/10 & 0.3277 & $* * *$ & $(0.0192)$ & -0.1033 & $* * *$ & $(0.0342)$ \\
\hline Experience squared/100 & -0.1143 & $* * *$ & $(0.0106)$ & 0.0368 & $* *$ & $(0.0174)$ \\
\hline Experience cubic/1000 & 0.0121 & $* * *$ & $(0.0017)$ & -0.0033 & & $(0.0027)$ \\
\hline \multicolumn{7}{|l|}{ Immigrant-specific characteristics } \\
\hline Years since migration/10 & & & & 0.0092 & & $(0.0353)$ \\
\hline Years since migration squared/100 & & & & 0.0224 & & $(0.0161)$ \\
\hline Years since migration cubic/1000 & & & & -0.0042 & $*$ & $(0.0024)$ \\
\hline Years since migration jointly ${ }^{\dagger}$ & & & & 6.39 & $* * *$ & \\
\hline Observations & 73,801 & & & & & \\
\hline Persons & 10,604 & & & & & \\
\hline $\mathrm{R}^{2}$ & 0.4518 & $* * *$ & & & & \\
\hline
\end{tabular}

Note: Dependent variable log real gross hourly wage. Regression controls for a third degree polynomial in tenure, marital status, self-employment, number of children in household, average yearly unemployment rate, occupation and industry, geographical and community background. For immigrants, controls for citizenship, arrival cohort, age at migration, country of origin, and language skills were included in addition to the ysm polynomial. Coefficients for immigrants refer to interactions with an immigrant dummy variable. Clustered standard errors (by person) in parentheses. $* * * / * * / *$ refer to statistical significance at the $1 \% / 5 \% / 10 \%$ level. See Appendix Table A2 for details.

†: Value of the F-statistic.

Source: Own calculations based on SOEP, years 1984-2009. 
Table 4: Estimation results by skill group

\begin{tabular}{|c|c|c|c|c|c|c|}
\hline & \multicolumn{2}{|l|}{ High skilled } & \multicolumn{2}{|c|}{ Medium skilled } & \multicolumn{2}{|l|}{ Low skilled } \\
\hline & & & & & \multicolumn{2}{|c|}{ Natives } \\
\hline Experience/10 & $\begin{array}{r}0.4519 \\
(0.0392)\end{array}$ & $* * *$ & $\begin{array}{r}0.2981 \\
(0.0242)\end{array}$ & $* * *$ & $\begin{array}{r}0.2523 \\
(0.0479)\end{array}$ & $* * *$ \\
\hline Experience squared/100 & $\begin{array}{r}-0.1582 \\
(0.0217)\end{array}$ & $* * *$ & $\begin{array}{r}-0.1086 \\
(0.0136)\end{array}$ & $* * *$ & $\begin{array}{c}-0.0738 \\
(0.0252)\end{array}$ & $* * *$ \\
\hline Experience cubic/1000 & $\begin{array}{r}0.0176 \\
(0.0035)\end{array}$ & $* * *$ & $\begin{array}{r}0.0119 \\
(0.0022)\end{array}$ & $* * *$ & $\begin{array}{r}0.0059 \\
(0.0038)\end{array}$ & \\
\hline \multicolumn{7}{|l|}{ Immigrant interactions } \\
\hline Experience/10 & $\begin{array}{c}-0.1831 \\
(0.1029)\end{array}$ & $*$ & $\begin{array}{r}-0.1013 \\
(0.0459)\end{array}$ & $* *$ & $\begin{array}{r}-0.0213 \\
(0.0643)\end{array}$ & \\
\hline Experience squared/100 & $\begin{array}{r}0.0686 \\
(0.0547)\end{array}$ & & $\begin{array}{r}0.0498 \\
(0.0237)\end{array}$ & $* *$ & $\begin{array}{r}-0.0054 \\
(0.0320)\end{array}$ & \\
\hline Experience cubic/1000 & $\begin{array}{r}-0.0089 \\
(0.0087)\end{array}$ & & $\begin{array}{r}-0.0064 \\
(0.0037)\end{array}$ & $*$ & $\begin{array}{r}0.0036 \\
(0.0047)\end{array}$ & \\
\hline Years since migration/10 & $\begin{array}{r}0.0897 \\
(0.0932)\end{array}$ & & $\begin{array}{r}-0.0338 \\
(0.0538)\end{array}$ & & $\begin{array}{r}-0.0106 \\
(0.0642)\end{array}$ & \\
\hline Years since migration squared/100 & $\begin{array}{r}-0.0087 \\
(0.0444)\end{array}$ & & $\begin{array}{r}0.0473 \\
(0.0264)\end{array}$ & $*$ & $\begin{array}{r}0.0307 \\
(0.0295)\end{array}$ & \\
\hline Years since migration cubic/1000 & $\begin{array}{r}0.0019 \\
(0.0061)\end{array}$ & & $\begin{array}{r}-0.0092 \\
(0.0041)\end{array}$ & $* *$ & $\begin{array}{r}-0.0053 \\
(0.0042)\end{array}$ & \\
\hline Years since migration jointly ${ }^{\dagger}$ & 1.60 & & 3.72 & $* *$ & 3.03 & $* *$ \\
\hline $\begin{array}{l}\text { Observations } \\
\text { Persons }\end{array}$ & $\begin{array}{r}20,786 \\
3,251\end{array}$ & & $\begin{array}{r}39,525 \\
6,077\end{array}$ & & $\begin{array}{r}13,490 \\
2,134\end{array}$ & \\
\hline $\mathrm{R}^{2}$ & 0.3679 & $* * *$ & 0.3097 & $* * *$ & 0.3572 & $* * *$ \\
\hline
\end{tabular}

Note: Dependent variable log real gross hourly wage. Regression controls for a third degree polynomial in tenure, marital status, self-employment, number of children in household, average yearly unemployment rate, occupation and industry, geographical and community background. For immigrants, controls for citizenship, arrival cohort, age at migration, country of origin, and language skills were included in addition to the ysm polynomial. Coefficients for immigrants refer to interactions with an immigrant dummy variable. Clustered standard errors (by person) in parentheses. $* * * * * * *$ refer to statistical significance at the 1\%/5\%/10\% level. See Appendix Tables A3-A5 for details.

t: Value of the F-statistic.

Source: Own calculations based on SOEP, years 1984-2009. 


\section{Figures}

Figure 1: Marginal effect of years since migration, all immigrants

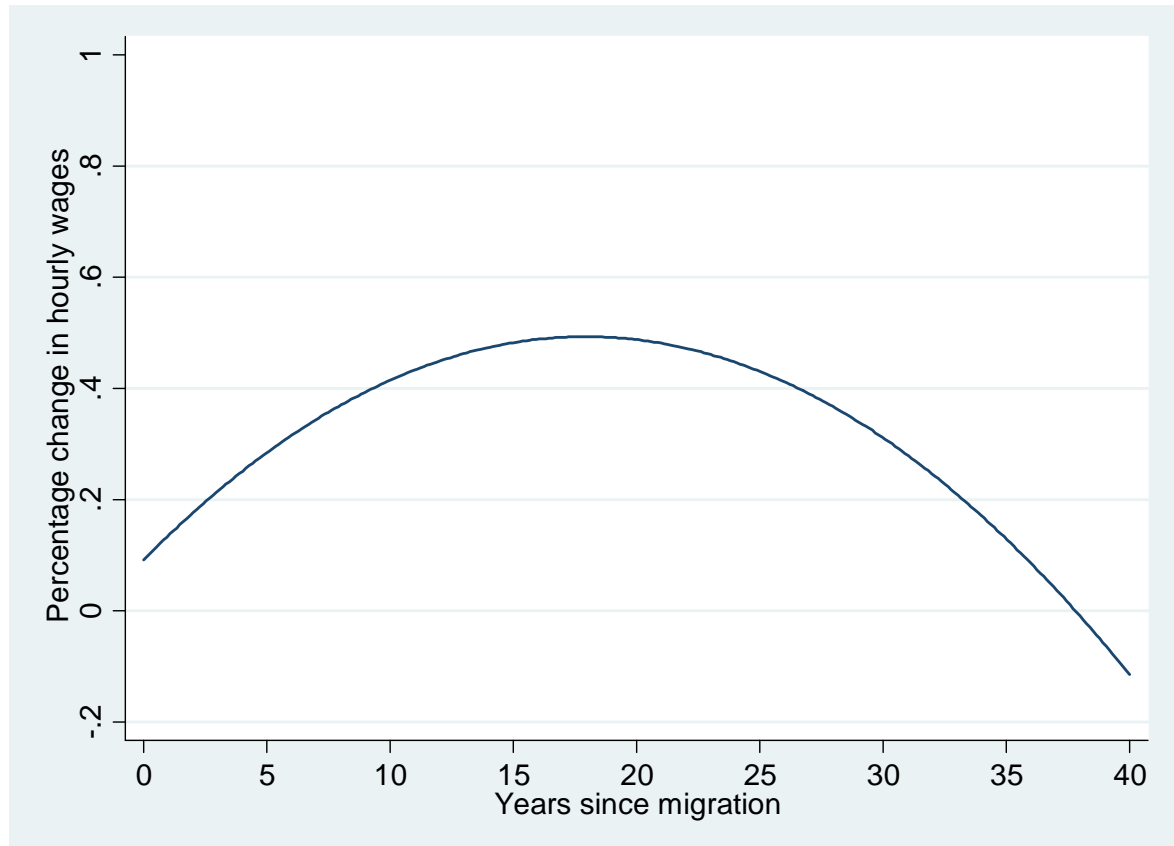

Note: Ceteris paribus effect of ysm on log hourly wages, based on Table 3. Source: Own calculations based on SOEP, years 1984-2009.

Figure 2: Predicted experience earnings profiles, all skill groups

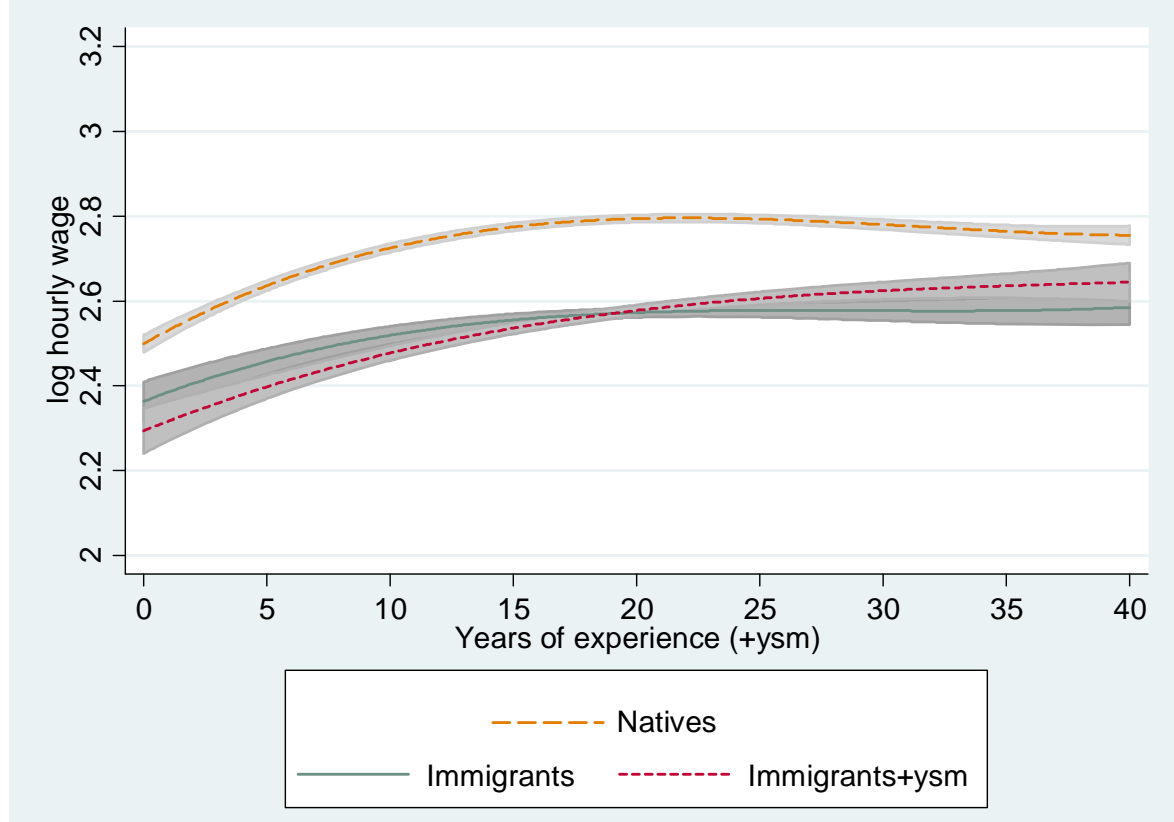

Note: Personal characteristics for immigrants and natives were set to their respective means. "Immigrants+ysm" refers to the predicted log hourly wage of immigrants for whom experience and ysm go hand in hand, i.e., all experience is acquired in Germany as soon as the immigrant arrives. The shaded areas represent 95\% confidence intervals.

Source: Own calculations based on SOEP, years 1984-2009. 
Figure 3: Marginal effect of experience and experience + ysm, all skill groups

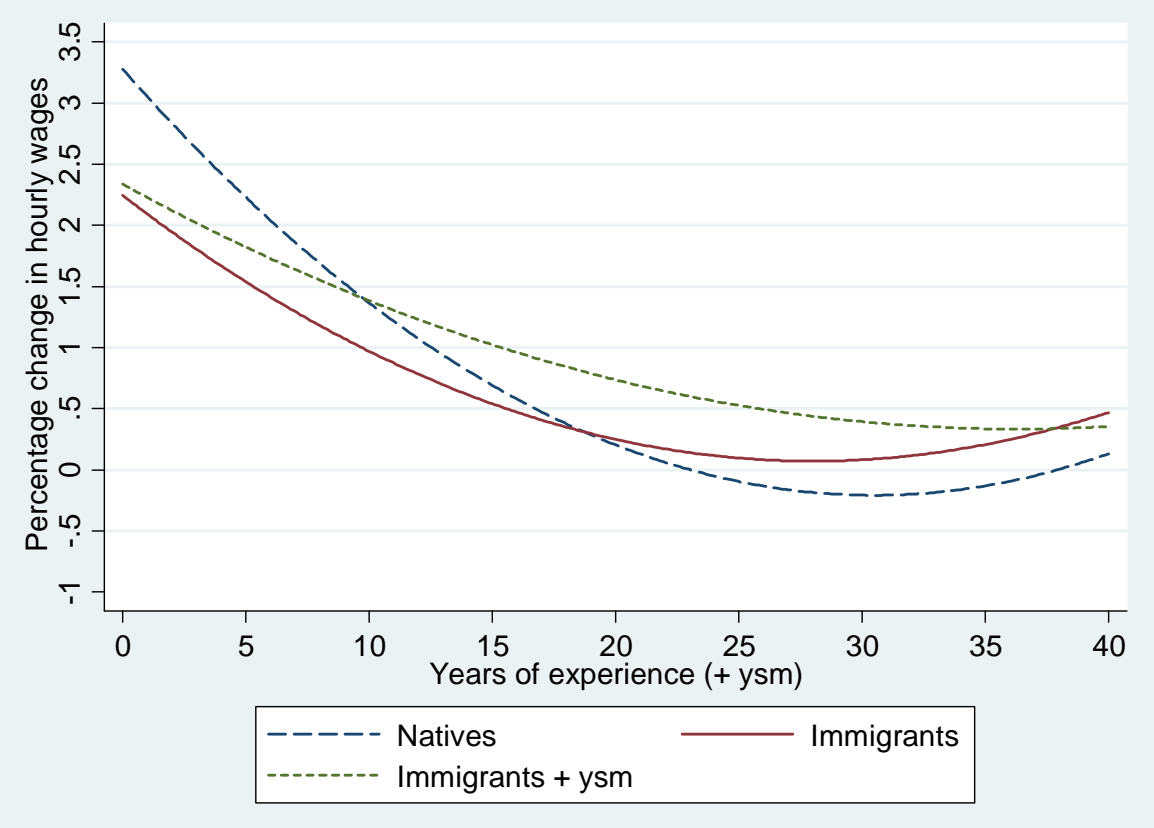

Source: Own calculations based on SOEP, years 1984-2009. Results based on Table 3.

Figure 4: Marginal effect of years since migration for highly, medium, and low skilled immigrants

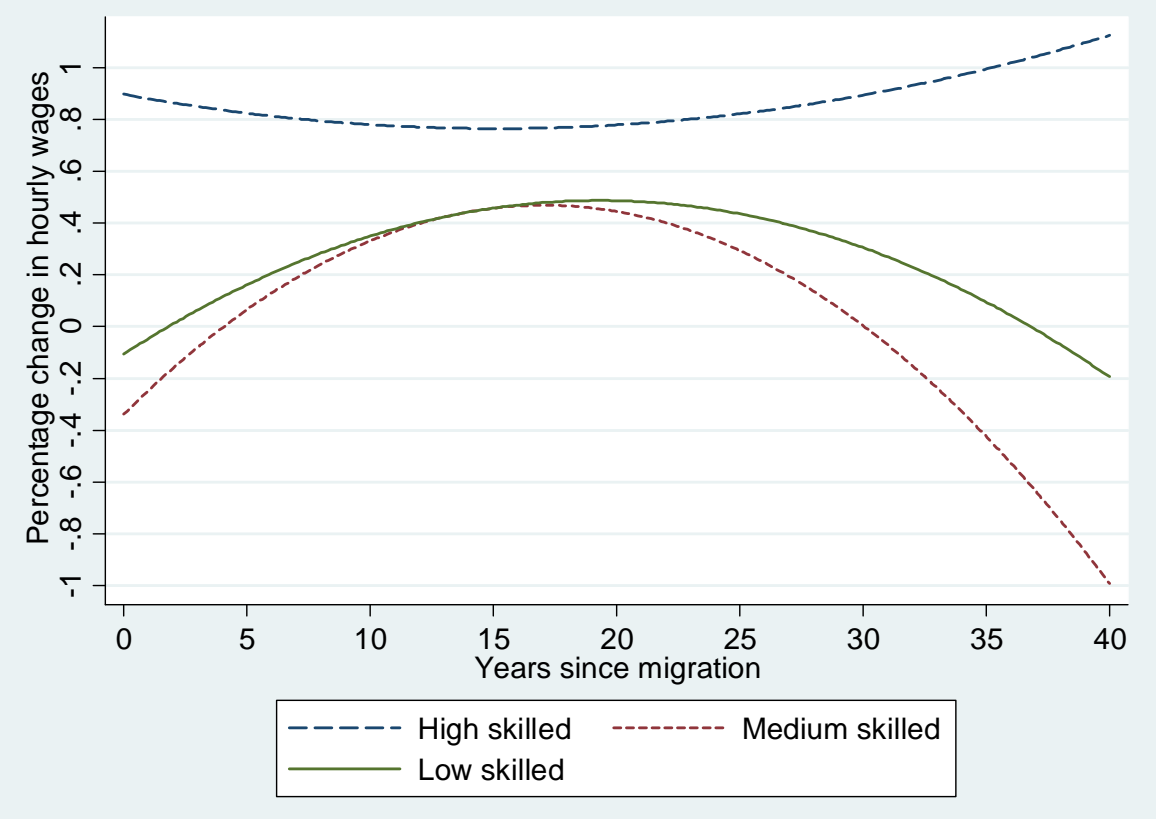

Note: Ceteris paribus effect of ysm on log hourly wages, based on Table 4. Source: Own calculations based on SOEP, years 1984-2009. 
Figure 5: Comparison of the predicted experience earnings profiles of highly, medium, and low skilled immigrants

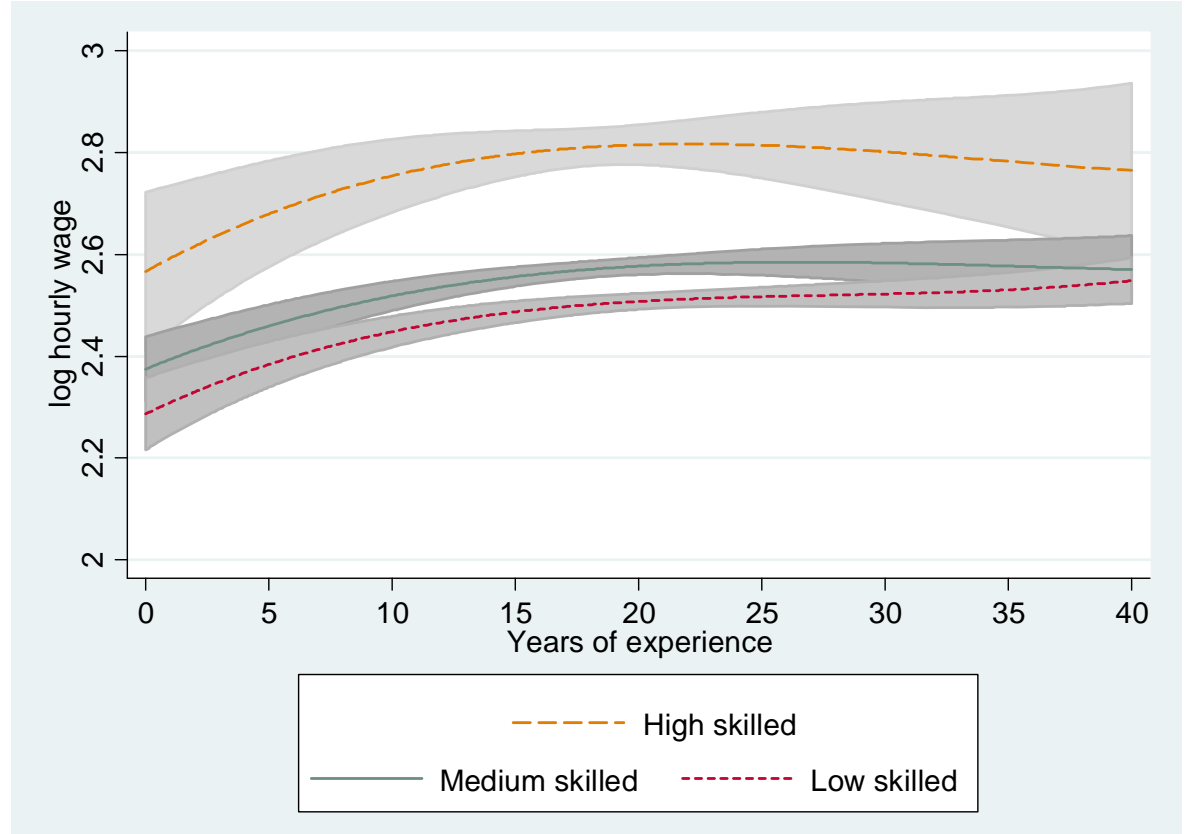

Note: Values of the explanatory variables for highly, medium, and low skilled immigrants are set to their respective means. Ysm is held constant. See Tables A2-A4 for details. The shaded areas represent $95 \%$ confidence intervals.

Source: Own calculations based on SOEP, years 1984-2009. 


\section{Appendix}

Table A 1: Model comparison, alternative specifications

\begin{tabular}{|c|c|c|c|c|c|c|c|c|c|c|c|c|}
\hline \multirow[b]{2}{*}{ Natives } & \multicolumn{2}{|l|}{ Model I } & \multicolumn{2}{|l|}{ Model II } & \multicolumn{2}{|l|}{ Modell III } & \multicolumn{2}{|l|}{ Model IV } & \multicolumn{2}{|l|}{ Model V } & \multicolumn{2}{|l|}{ Model VI } \\
\hline & & & & & & & & & & & & \\
\hline Experience/10 & $\begin{array}{r}0.2921 \\
(0.0219)\end{array}$ & $* * *$ & $\begin{array}{r}0.2922 \\
(0.0217)\end{array}$ & $* * *$ & $\begin{array}{r}0.3277 \\
(0.0192)\end{array}$ & $* * *$ & $\begin{array}{r}0.3277 \\
(0.0192)\end{array}$ & $* * *$ & $\begin{array}{r}0.3277 \\
(0.0192)\end{array}$ & $* * *$ & $\begin{array}{r}0.3277 \\
(0.0192)\end{array}$ & $* * *$ \\
\hline Experience squared/100 & $\begin{array}{r}-0.1007 \\
(0.0122)\end{array}$ & $* * *$ & $\begin{array}{r}-0.1009 \\
(0.0122)\end{array}$ & $* * *$ & $\begin{array}{r}-0.1143 \\
(0.0106)\end{array}$ & $* * *$ & $\begin{array}{r}-0.1143 \\
(0.0106)\end{array}$ & $* * *$ & $\begin{array}{r}-0.1143 \\
(0.0106)\end{array}$ & $* * *$ & $\begin{array}{r}-0.1143 \\
(0.0106)\end{array}$ & $* * *$ \\
\hline Experience cubic/1000 & $\begin{array}{r}0.0098 \\
(0.0020) \\
\end{array}$ & $* * *$ & $\begin{array}{r}0.0099 \\
(0.0020) \\
\end{array}$ & $* * *$ & $\begin{array}{r}0.0121 \\
(0.0017) \\
\end{array}$ & $* * *$ & $\begin{array}{r}0.0121 \\
(0.0017) \\
\end{array}$ & $* * *$ & $\begin{array}{r}0.0121 \\
(0.0017) \\
\end{array}$ & $* * *$ & $\begin{array}{r}0.0121 \\
(0.0017) \\
\end{array}$ & $* * *$ \\
\hline \multicolumn{13}{|l|}{ Immigrant interactions } \\
\hline Experience/10 & $\begin{array}{r}-0.1137 \\
(0.0371)\end{array}$ & $* * *$ & $\begin{array}{r}-0.1111 \\
(0.0369)\end{array}$ & $* * *$ & $\begin{array}{r}-0.1065 \\
(0.0337)\end{array}$ & $* * *$ & $\begin{array}{r}-0.1115 \\
(0.0335)\end{array}$ & $* * *$ & $\begin{array}{r}-0.1053 \\
(0.0343)\end{array}$ & $* * *$ & $\begin{array}{r}-0.1033 \\
(0.0342)\end{array}$ & $* * *$ \\
\hline Experience squared/100 & $\begin{array}{r}0.0362 \\
(0.0191)\end{array}$ & * & $\begin{array}{r}0.0353 \\
(0.0191)\end{array}$ & $*$ & $\begin{array}{r}0.0336 \\
(0.0173)\end{array}$ & $*$ & $\begin{array}{r}0.0401 \\
(0.0172)\end{array}$ & $* *$ & $\begin{array}{r}0.0372 \\
(0.0174)\end{array}$ & $* *$ & $\begin{array}{r}0.0368 \\
(0.0174)\end{array}$ & $* *$ \\
\hline Experience cubic/1000 & $\begin{array}{l}-0.0026 \\
(0.0029)\end{array}$ & & $\begin{array}{r}-0.0026 \\
(0.0029)\end{array}$ & & $\begin{array}{r}-0.0026 \\
(0.0027)\end{array}$ & & $\begin{array}{r}-0.0037 \\
(0.0026)\end{array}$ & & $\begin{array}{r}-0.0032 \\
(0.0027)\end{array}$ & & $\begin{array}{r}-0.0033 \\
(0.0027)\end{array}$ & \\
\hline Years since migration/10 & $\begin{array}{r}-0.0124 \\
(0.0366)\end{array}$ & & $\begin{array}{r}-0.0134 \\
(0.0364)\end{array}$ & & $\begin{array}{r}-0.0368 \\
(0.0329)\end{array}$ & & $\begin{array}{r}0.0361 \\
(0.0347)\end{array}$ & & $\begin{array}{r}0.0154 \\
(0.0353)\end{array}$ & & $\begin{array}{r}0.0092 \\
(0.0353)\end{array}$ & \\
\hline $\begin{array}{l}\text { Years since migration } \\
\text { squared/100 }\end{array}$ & $\begin{array}{r}0.0257 \\
(0.0171)\end{array}$ & & $\begin{array}{r}0.0255 \\
(0.0170)\end{array}$ & & $\begin{array}{r}0.0260 \\
(0.0152)\end{array}$ & $*$ & $\begin{array}{r}0.0102 \\
(0.0154)\end{array}$ & & $\begin{array}{r}0.0212 \\
(0.0161)\end{array}$ & & $\begin{array}{r}0.0224 \\
(0.0161)\end{array}$ & \\
\hline $\begin{array}{l}\text { Years since migration } \\
\text { cubic/1000 }\end{array}$ & $\begin{array}{r}-0.0040 \\
(0.0025)\end{array}$ & & $\begin{array}{l}-0.0040 \\
(0.0025)\end{array}$ & & $\begin{array}{l}-0.0036 \\
(0.0022)\end{array}$ & $*$ & $\begin{array}{l}-0.0022 \\
(0.0022)\end{array}$ & & $\begin{array}{l}-0.0042 \\
(0.0024)\end{array}$ & * & $\begin{array}{r}-0.0042 \\
(0.0024)\end{array}$ & $*$ \\
\hline Years since migration jointly ${ }^{\dagger}$ & 3.85 & $* * *$ & 3.69 & $* *$ & 1.74 & & 7.30 & $* * *$ & 6.99 & $* * *$ & 6.39 & $* * *$ \\
\hline $\begin{array}{l}\text { Regional / Community size } \\
\text { dummies }\end{array}$ & NO & & YES & $* * *$ & YES & $* * *$ & YES & $* * *$ & YES & $* * *$ & YES & $* * *$ \\
\hline $\begin{array}{l}\text { Industry and occupational } \\
\text { dummies }\end{array}$ & NO & & NO & & YES & $* * *$ & YES & $* * *$ & YES & $* * *$ & YES & $* * *$ \\
\hline $\begin{array}{l}\text { Immigrant-specific } \\
\text { characteristics }\end{array}$ & & & & & & & & & & & & \\
\hline Arrival cohort dummies & NO & & NO & & NO & & YES & $* * *$ & YES & $* * *$ & YES & $* * *$ \\
\hline Country of origin dummies & NO & & NO & & NO & & NO & & YES & $* * *$ & YES & $* * *$ \\
\hline $\begin{array}{l}\text { German language ability } \\
\text { dummies }\end{array}$ & NO & & NO & & NO & & NO & & NO & & YES & $* * *$ \\
\hline Observations & 73,801 & & 73,801 & & 73,801 & & 73,801 & & 73,801 & & 73,801 & \\
\hline Persons & 10,604 & & 10,604 & & 10,604 & & 10,604 & & 10,604 & & 10,604 & \\
\hline $\mathrm{R}^{2}$ & 0.3314 & $* * *$ & 0.3371 & $* * *$ & 0.4489 & $* * *$ & 0.4502 & $* * *$ & 0.4515 & $* * *$ & 0.4518 & $* * *$ \\
\hline Adjusted $\mathrm{R}^{2}$ & 0.3312 & & 0.3367 & & 0.4483 & & 0.4497 & & 0.4509 & & 0.4512 & \\
\hline
\end{tabular}

Note: Dependent variable log real gross hourly wage. Regression controls for a third degree polynomial in tenure, marital status, self-employment, number of children in household, and average yearly unemployment rate. For immigrants, controls for citizenship and age at migration were added in addition to the ysm polynomial. Coefficients for immigrants refer to interactions with an immigrant dummy variable. Clustered standard errors (by person) in parentheses. $* * * / * * / *$ refer to statistical significance at the $1 \% / 5 \% / 10 \%$ level.

t: Value of the F-statistic.

Source: Own calculations based on SOEP, years 1984-2009. 
Table A 2: Full OLS estimation results, all skill groups

\begin{tabular}{|c|c|c|c|c|c|c|}
\hline & \multicolumn{3}{|c|}{ Natives } & \multicolumn{3}{|c|}{ Immigrant Interactions } \\
\hline & Coefficient & & Standard error & Coefficient & & Standard error \\
\hline \multicolumn{7}{|l|}{ Personal characteristics } \\
\hline Experience/10 & 0.3277 & $* * *$ & $(0.0192)$ & -0.1033 & $* * *$ & $(0.0342)$ \\
\hline Experience squared/100 & -0.1143 & $* * *$ & $(0.0106)$ & 0.0368 & $* *$ & $(0.0174)$ \\
\hline Experience cubic/1000 & 0.0121 & $* * *$ & $(0.0017)$ & -0.0033 & & $(0.0027)$ \\
\hline Tenure/10 & 0.1771 & $* * *$ & $(0.0157)$ & 0.0727 & $* *$ & $(0.0297)$ \\
\hline Tenure squared/100 & -0.0567 & $* * *$ & $(0.0100)$ & -0.0643 & $* * *$ & $(0.0213)$ \\
\hline Tenure cubic/1000 & 0.0071 & $* * *$ & $(0.0017)$ & 0.0134 & $* * *$ & $(0.0043)$ \\
\hline $\begin{array}{l}\text { Self-employed (=1 if person is self-employed, } \\
=0 \text { otherwise) }\end{array}$ & -0.0471 & $* * *$ & $(0.0163)$ & -0.0054 & & $(0.0130)$ \\
\hline Married (=1 if person is married, $=0$ otherwise) & 0.0406 & $* * *$ & $(0.0069)$ & 0.0730 & * & $(0.0391)$ \\
\hline Number of children in household & 0.0120 & $* * *$ & $(0.0031)$ & -0.0060 & & $(0.0045)$ \\
\hline average yearly unemployment rate & 0.0049 & $* * *$ & $(0.0011)$ & -0.0124 & $* * *$ & $(0.0021)$ \\
\hline \multicolumn{7}{|l|}{ Residence-Dummies } \\
\hline South Germany & 0.0130 & $*$ & $(0.0067)$ & 0.0041 & & $(0.0112)$ \\
\hline Central Germany & -Reference- & & & -Reference- & & \\
\hline North Germany & -0.0180 & $* *$ & $(0.0086)$ & 0.0143 & & $(0.0174)$ \\
\hline Community $<20,000$ inhabitants & -0.0273 & $* * *$ & $(0.0080)$ & 0.0295 & & $(0.0192)$ \\
\hline Community 20,000-100,000 inhabitants & -Reference- & & & -Reference- & & \\
\hline Community $>100,000$ inhabitants & 0.0181 & $* * *$ & $(0.0069)$ & 0.0048 & & $(0.0109)$ \\
\hline \multicolumn{7}{|l|}{ Qualification level } \\
\hline High-skilled (ISCED 5 - 6) & 0.1651 & $* * *$ & $(0.0086)$ & -0.0642 & $* * *$ & $(0.0205)$ \\
\hline Medium-skilled (ISCED 3 - 4) & -Reference- & & & -Reference- & & \\
\hline Low-skilled (ISCED 1 - 2) & -0.0532 & $* * *$ & $(0.0082)$ & 0.0190 & & $(0.0118)$ \\
\hline \multicolumn{7}{|l|}{ Occupation } \\
\hline $\begin{array}{l}\text { ISCO1 - Legislators, senior officials and } \\
\text { managers }\end{array}$ & 0.2785 & $* * *$ & $(0.0131)$ & -0.2361 & $* * *$ & $(0.0396)$ \\
\hline ISCO2 - Professionals & 0.3222 & $* * *$ & $(0.0106)$ & -0.0474 & & $(0.0296)$ \\
\hline ISCO3 - Technicians and associate professionals & 0.1727 & $* * *$ & $(0.0091)$ & -0.0852 & $* * *$ & $(0.0202)$ \\
\hline ISCO4 - Clerks & 0.0861 & $* * *$ & $(0.0119)$ & -0.1033 & $* * *$ & $(0.0252)$ \\
\hline $\begin{array}{l}\text { ISCO5 - Service workers and shop and market } \\
\text { sales worker }\end{array}$ & -0.0281 & $* *$ & $(0.0140)$ & -0.1446 & $* * *$ & $(0.0410)$ \\
\hline ISCO6 - Skilled agricultural and fishery workers & -0.0680 & * & $(0.0376)$ & 0.0640 & & $(0.0653)$ \\
\hline ISCO7 - Craft and related trades workers & -Reference- & & & -Reference- & & \\
\hline $\begin{array}{l}\text { ISCO8 - Plant and machine operators and } \\
\text { assmblers }\end{array}$ & -0.0443 & $* * *$ & $(0.0100)$ & 0.0113 & & $(0.0133)$ \\
\hline ISCO9 - Elementary occupations & -0.0685 & $* * *$ & $(0.0126)$ & -0.0084 & & $(0.0162)$ \\
\hline ISCO N.A. & 0.0869 & $* * *$ & $(0.0162)$ & -0.1148 & $* * *$ & $(0.0231)$ \\
\hline \multicolumn{7}{|l|}{ Industry } \\
\hline Manufactoring & -Reference- & & & -Reference- & & \\
\hline Agriculture / Fishery & -0.2805 & $* * *$ & $(0.0272)$ & 0.1074 & $* *$ & $(0.0498)$ \\
\hline Construction & -0.0728 & $* * *$ & $(0.0090)$ & 0.0172 & & $(0.0133)$ \\
\hline Trade, transportation, communication & -0.1485 & $* * *$ & $(0.0091)$ & 0.0454 & $* * *$ & $(0.0158)$ \\
\hline $\begin{array}{l}\text { Credit institutions, housing, } \\
\text { business-related services }\end{array}$ & 0.0682 & $* * *$ & $(0.0111)$ & -0.0663 & $* *$ & $(0.0288)$ \\
\hline Public administration / services & -0.1331 & $* * *$ & $(0.0082)$ & 0.0551 & $* * *$ & $(0.0212)$ \\
\hline Miscellaneous & -0.0734 & $* * *$ & $(0.0175)$ & -0.0531 & $*$ & $(0.0319)$ \\
\hline N.A. & -0.1176 & $* * *$ & $(0.0135)$ & 0.0770 & $* * *$ & $(0.0184)$ \\
\hline \multicolumn{7}{|l|}{ Immigrant-specific characteristics } \\
\hline Years since migration/10 & & & & 0.0092 & & $(0.0353)$ \\
\hline Years since migration squared/100 & & & & 0.0224 & & $(0.0161)$ \\
\hline Years since migration cubic/1000 & & & & -0.0042 & $*$ & $(0.0024)$ \\
\hline Age at migration & & & & -0.0047 & $* * *$ & $(0.0009)$ \\
\hline
\end{tabular}




\section{Table A 2 continued}

\begin{tabular}{|c|c|c|c|c|c|c|}
\hline \multicolumn{7}{|l|}{ Immigration cohorts } \\
\hline 1973 and before & & & & -Reference- & & \\
\hline 1974-1988 & & & & 0.0610 & $* * *$ & $(0.0122)$ \\
\hline 1989 and after & & & & 0.1174 & $* * *$ & $(0.0181)$ \\
\hline \multicolumn{7}{|l|}{ Country of origin } \\
\hline Turkey & & & & -Reference- & & \\
\hline Italy & & & & -0.0346 & $* * *$ & $(0.0131)$ \\
\hline Former Yugoslavia & & & & 0.0206 & & $(0.0134)$ \\
\hline Greece & & & & 0.0071 & & $(0.0178)$ \\
\hline Portugal and Spain & & & & -0.0040 & & $(0.0158)$ \\
\hline other Western Countries & & & & 0.1142 & $* * *$ & $(0.0346)$ \\
\hline Eastern Europe & & & & 0.0054 & & $(0.0196)$ \\
\hline Asia & & & & -0.0445 & $*$ & $(0.0242)$ \\
\hline Spoken German (very) good & & & & 0.0146 & * & $(0.0078)$ \\
\hline Spoken German missing & & & & -0.0095 & & $(0.0380)$ \\
\hline Written German (very) good & & & & 0.0290 & $* * *$ & $(0.0091)$ \\
\hline Written German missing & & & & 0.0277 & & $(0.0368)$ \\
\hline German citizenship & & & & 0.0092 & & $(0.0171)$ \\
\hline Constant & 2.1875 & $* * *$ & $(0.0143)$ & 0.0809 & * & $(0.0433)$ \\
\hline Observations & 73,801 & & & & & \\
\hline Persons & 10,604 & & & & & \\
\hline $\mathrm{R}^{2}$ & 0.4518 & $* * *$ & & & & \\
\hline
\end{tabular}

Note: Dependent variable log real gross hourly wage. Coefficients for immigrants refer to interactions with an immigrant indicator variable. Clustered standard errors (by person) in parentheses. ***/**/* refer to statistical significance at the $1 \% / 5 \% / 10 \%$ level.

Source: Own calculations based on SOEP, years 1984-2009.

Table A 3: Full estimation results, highly skilled

\begin{tabular}{|c|c|c|c|c|c|c|}
\hline & \multicolumn{3}{|c|}{ Natives } & \multicolumn{3}{|c|}{ Immigrant Interactions } \\
\hline & Coefficient & & Standard error & Coefficient & & Standard error \\
\hline \multicolumn{7}{|l|}{ Personal characteristics } \\
\hline Experience/10 & 0.4519 & $* * *$ & $(0.0392)$ & -0.1831 & * & $(0.1029)$ \\
\hline Experience squared/100 & -0.1582 & $* * *$ & $(0.0217)$ & 0.0686 & & $(0.0547)$ \\
\hline Experience cubic/1000 & 0.0176 & $* * *$ & $(0.0035)$ & -0.0089 & & $(0.0087)$ \\
\hline Tenure/10 & 0.1529 & $* * *$ & $(0.0294)$ & -0.0446 & & $(0.0806)$ \\
\hline Tenure squared/100 & -0.0565 & $* * *$ & $(0.0186)$ & -0.0031 & & $(0.0561)$ \\
\hline Tenure cubic/1000 & 0.0069 & $* *$ & $(0.0033)$ & 0.0026 & & $(0.0100)$ \\
\hline $\begin{array}{l}\text { Self-employed (= } 1 \text { if person is self-employed, } \\
=0 \text { otherwise) }\end{array}$ & -0.0641 & $* * *$ & $(0.0249)$ & -0.0191 & & $(0.0363)$ \\
\hline Married ( $=1$ if person is married, $=0$ otherwise) & 0.0464 & $* * *$ & $(0.0134)$ & 0.0209 & & $(0.0509)$ \\
\hline Number of children in household & 0.0192 & $* * *$ & $(0.0053)$ & -0.0137 & & $(0.0117)$ \\
\hline average yearly unemployment rate & 0.0056 & $* * *$ & $(0.0020)$ & -0.0052 & & $(0.0063)$ \\
\hline \multicolumn{7}{|l|}{ Residence-Dummies } \\
\hline South Germany & 0.0089 & & $(0.0115)$ & 0.0540 & * & $(0.0326)$ \\
\hline Central Germany & -Reference- & & & -Reference- & & \\
\hline North Germany & -0.0226 & & $(0.0155)$ & 0.0279 & & $(0.0441)$ \\
\hline Community $<20,000$ inhabitants & -0.0297 & $* *$ & $(0.0148)$ & -0.0660 & & $(0.0504)$ \\
\hline Community 20,000-100,000 inhabitants & -Reference- & & & -Reference- & & \\
\hline Community $>100,000$ inhabitants & 0.0190 & * & $(0.0114)$ & -0.0116 & & $(0.0276)$ \\
\hline
\end{tabular}




\section{Table A 3 continued}

\begin{tabular}{|c|c|c|c|c|c|c|}
\hline \multicolumn{7}{|l|}{ Occupation } \\
\hline $\begin{array}{l}\text { ISCO1 - Legislators, senior officials and } \\
\text { managers }\end{array}$ & 0.4170 & $* * *$ & $(0.0226)$ & -0.1226 & $* *$ & $(0.0487)$ \\
\hline ISCO2 - Professionals & 0.4510 & $* * *$ & $(0.0183)$ & -0.0792 & & $(0.0483)$ \\
\hline ISCO3 - Technicians and associate professionals & 0.2730 & $* * *$ & $(0.0200)$ & -0.0541 & & $(0.0520)$ \\
\hline ISCO4 - Clerks & 0.2421 & $* * *$ & $(0.0312)$ & -0.2048 & $* * *$ & $(0.0775)$ \\
\hline $\begin{array}{l}\text { ISCO5 - Service workers and shop and market } \\
\text { sales worker }\end{array}$ & -0.0295 & & $(0.0513)$ & -0.0519 & & $(0.0858)$ \\
\hline ISCO6 - Skilled agricultural and fishery workers & 0.0738 & & $(0.0812)$ & 0.5240 & $* * *$ & $(0.1292)$ \\
\hline ISCO7 - Craft and related trades workers & -Reference- & & & -Reference- & & \\
\hline $\begin{array}{l}\text { ISCO8 - Plant and machine operators and } \\
\text { assmblers }\end{array}$ & 0.0178 & & $(0.0513)$ & -0.0281 & & $(0.0657)$ \\
\hline ISCO9 - Elementary occupations & 0.0090 & & $(0.0619)$ & -0.0495 & & $(0.0742)$ \\
\hline ISCO N.A. & 0.3070 & $* * *$ & $(0.0382)$ & -0.1351 & & $(0.0923)$ \\
\hline \multicolumn{7}{|l|}{ Industry } \\
\hline Manufactoring & -Reference- & & & -Reference- & & \\
\hline Agriculture / Fishery & -0.2786 & $* * *$ & $(0.0613)$ & -0.1891 & $* *$ & $(0.0964)$ \\
\hline Construction & -0.0960 & $* * *$ & $(0.0213)$ & -0.0150 & & (0.0449) \\
\hline Trade, transportation, communication & -0.1268 & $* * *$ & $(0.0218)$ & -0.0067 & & $(0.0448)$ \\
\hline $\begin{array}{l}\text { Credit institutions, housing, } \\
\text { business-related services }\end{array}$ & 0.0523 & $* * *$ & $(0.0168)$ & -0.0390 & & $(0.0508)$ \\
\hline Public administration / services & -0.1753 & $* * *$ & $(0.0126)$ & 0.0702 & $*$ & $(0.0412)$ \\
\hline Miscellaneous & -0.0366 & & $(0.0310)$ & -0.1156 & & $(0.0960)$ \\
\hline N.A. & -0.1120 & $* * *$ & $(0.0294)$ & 0.1402 & $* *$ & $(0.0672)$ \\
\hline \multicolumn{7}{|l|}{ Immigrant-specific characteristics } \\
\hline Years since migration/10 & & & & 0.0897 & & $(0.0932)$ \\
\hline Years since migration squared/100 & & & & -0.0087 & & $(0.0444)$ \\
\hline Years since migration cubic/1000 & & & & 0.0019 & & $(0.0061)$ \\
\hline Age at migration & & & & -0.0030 & & $(0.0038)$ \\
\hline \multicolumn{7}{|l|}{ Immigration cohorts } \\
\hline 1973 and before & & & & -Reference- & & \\
\hline 1974-1988 & & & & 0.0999 & $* *$ & $(0.0441)$ \\
\hline 1989 and after & & & & 0.1651 & $* * *$ & $(0.0576)$ \\
\hline \multicolumn{7}{|l|}{ Country of origin } \\
\hline Turkey & & & & -Reference- & & \\
\hline Italy & & & & 0.0731 & & $(0.0693)$ \\
\hline Former Yugoslavia & & & & 0.0342 & & $(0.0519)$ \\
\hline Greece & & & & 0.0387 & & $(0.0890)$ \\
\hline Portugal and Spain & & & & 0.0258 & & $(0.0551)$ \\
\hline other Western Countries & & & & 0.1632 & $* * *$ & $(0.0579)$ \\
\hline Eastern Europe & & & & 0.0606 & & $(0.0431)$ \\
\hline Asia & & & & -0.0404 & & $(0.0487)$ \\
\hline Spoken German (very) good & & & & 0.0510 & & $(0.0344)$ \\
\hline Spoken German missing & & & & 0.0879 & $* *$ & $(0.0375)$ \\
\hline Written German (very) good & & & & 0.0881 & $* * *$ & $(0.0343)$ \\
\hline German citizenship & & & & -0.0498 & $* *$ & $(0.0338)$ \\
\hline Constant & 2.1754 & $* * *$ & $(0.0313)$ & -0.1286 & & $(0.1397)$ \\
\hline Observations & 20,786 & & & & & \\
\hline Persons & 3,251 & & & & & \\
\hline $\mathrm{R}^{2}$ & 0.3679 & $* * *$ & & & & \\
\hline
\end{tabular}

Note: Dependent variable log real gross hourly wage. Coefficients for immigrants refer to interactions with an immigrant indicator variable. Clustered standard errors (by person) in parentheses. $* * * / * * / *$ refer to statistical significance at the $1 \% / 5 \% / 10 \%$ level. Source: Own calculations based on SOEP, years 1984-2009. 
Table A 4: Full estimation results, medium skilled

\begin{tabular}{|c|c|c|c|c|c|c|}
\hline & \multicolumn{3}{|c|}{ Natives } & \multicolumn{3}{|c|}{ Immigrant Interactions } \\
\hline & Coefficient & & Standard error & Coefficient & & Standard error \\
\hline \multicolumn{7}{|l|}{ Personal characteristics } \\
\hline Experience/10 & 0.2981 & $* * *$ & $(0.0242)$ & -0.1013 & $* *$ & $(0.0459)$ \\
\hline Experience squared/100 & -0.1086 & $* * *$ & $(0.0136)$ & 0.0498 & $* *$ & $(0.0237)$ \\
\hline Experience cubic/1000 & 0.0119 & $* * *$ & $(0.0022)$ & -0.0064 & $*$ & $(0.0037)$ \\
\hline Tenure/10 & 0.1702 & $* * *$ & $(0.0205)$ & 0.1295 & $* * *$ & $(0.0395)$ \\
\hline Tenure squared/100 & -0.0399 & $* * *$ & $(0.0135)$ & -0.1198 & $* * *$ & $(0.0293)$ \\
\hline Tenure cubic/1000 & 0.0035 & & $(0.0024)$ & 0.0269 & $* * *$ & $(0.0060)$ \\
\hline $\begin{array}{l}\text { Self-employed (=1 if person is self-employed, } \\
=0 \text { otherwise) }\end{array}$ & 0.0017 & & $(0.0228)$ & 0.0040 & & $(0.0182)$ \\
\hline Married ( $=1$ if person is married, $=0$ otherwise) & 0.0416 & $* * *$ & $(0.0088)$ & 0.0876 & & $(0.0597)$ \\
\hline Number of children in household & 0.0045 & & $(0.0041)$ & -0.0021 & & $(0.0063)$ \\
\hline average yearly unemployment rate & 0.0054 & $* * *$ & $(0.0014)$ & -0.0109 & $* * *$ & $(0.0028)$ \\
\hline \multicolumn{7}{|l|}{ Residence-Dummies } \\
\hline South Germany & 0.0123 & & $(0.0091)$ & 0.0002 & & $(0.0157)$ \\
\hline Central Germany & -Reference- & & & -Reference- & & \\
\hline North Germany & -0.0193 & $*$ & $(0.0113)$ & 0.0048 & & $(0.0229)$ \\
\hline Community $<20,000$ inhabitants & -0.0157 & & $(0.0101)$ & 0.0147 & & $(0.0243)$ \\
\hline Community 20,000-100,000 inhabitants & -Reference- & & & -Reference- & & \\
\hline Community $>100,000$ inhabitants & 0.0260 & $* * *$ & $(0.0096)$ & -0.0102 & & $(0.0148)$ \\
\hline \multicolumn{7}{|l|}{ Occupation } \\
\hline $\begin{array}{l}\text { ISCO1 - Legislators, senior officials and } \\
\text { managers }\end{array}$ & 0.2112 & $* * *$ & $(0.0186)$ & -0.2244 & $* * *$ & $(0.0623)$ \\
\hline ISCO2 - Professionals & 0.2583 & $* * *$ & $(0.0198)$ & -0.1534 & $* *$ & $(0.0781)$ \\
\hline ISCO3 - Technicians and associate professionals & 0.1517 & $* * *$ & $(0.0111)$ & -0.1051 & $* * *$ & $(0.0245)$ \\
\hline ISCO4 - Clerks & 0.0699 & $* * *$ & $(0.0145)$ & -0.0758 & $* *$ & $(0.0310)$ \\
\hline $\begin{array}{l}\text { ISCO5 - Service workers and shop and market } \\
\text { sales worker }\end{array}$ & -0.0812 & $* * *$ & $(0.0178)$ & -0.0077 & & $(0.0490)$ \\
\hline ISCO6 - Skilled agricultural and fishery workers & -0.1066 & ** & $(0.0466)$ & -0.0039 & & $(0.0669)$ \\
\hline ISCO7 - Craft and related trades workers & -Reference- & & & -Reference- & & \\
\hline $\begin{array}{l}\text { ISCO8 - Plant and machine operators and } \\
\text { assmblers }\end{array}$ & -0.0524 & $* * *$ & $(0.0112)$ & 0.0090 & & $(0.0166)$ \\
\hline ISCO9 - Elementary occupations & -0.0689 & $* * *$ & $(0.0145)$ & -0.0341 & & $(0.0218)$ \\
\hline ISCO N.A. & 0.0403 & $* *$ & $(0.0199)$ & -0.0940 & $* * *$ & $(0.0287)$ \\
\hline \multicolumn{7}{|l|}{ Industry } \\
\hline Manufactoring & -Reference- & & & -Reference- & & \\
\hline Agriculture / Fishery & -0.2807 & $* * *$ & $(0.0381)$ & 0.1410 & $* * *$ & $(0.0499)$ \\
\hline Construction & -0.0722 & $* * *$ & $(0.0105)$ & 0.0083 & & $(0.0164)$ \\
\hline Trade, transportation, communication & -0.1410 & $* * *$ & $(0.0110)$ & 0.0197 & & $(0.0201)$ \\
\hline $\begin{array}{l}\text { Credit institutions, housing, } \\
\text { business-related services }\end{array}$ & 0.0734 & $* * *$ & $(0.0157)$ & -0.0410 & & $(0.0441)$ \\
\hline Public administration / services & -0.1119 & $* * *$ & $(0.0115)$ & 0.0554 & $*$ & $(0.0302)$ \\
\hline Miscellaneous & -0.0825 & $* * *$ & $(0.0208)$ & -0.1017 & $* *$ & $(0.0401)$ \\
\hline N.A. & -0.1229 & $* * *$ & $(0.0173)$ & 0.0836 & $* * *$ & $(0.0244)$ \\
\hline \multicolumn{7}{|l|}{ Immigrant-specific characteristics } \\
\hline Years since migration/10 & & & & -0.0338 & & $(0.0538)$ \\
\hline Years since migration squared/100 & & & & 0.0473 & $*$ & $(0.0264)$ \\
\hline Years since migration cubic/1000 & & & & -0.0092 & $* *$ & $(0.0041)$ \\
\hline Age at migration & & & & -0.0057 & $* * *$ & $(0.0014)$ \\
\hline \multicolumn{7}{|l|}{ Immigration cohorts } \\
\hline 1973 and before & & & & -Reference- & & \\
\hline 1974-1988 & & & & 0.0571 & $* * *$ & $(0.0169)$ \\
\hline 1989 and after & & & & 0.0957 & $* * *$ & $(0.0225)$ \\
\hline
\end{tabular}




\section{Table A 4 continued}

\begin{tabular}{|c|c|c|c|c|c|c|}
\hline \multicolumn{7}{|l|}{ Country of origin } \\
\hline Turkey & & & & -Reference- & & \\
\hline Italy & & & & -0.0333 & * & $(0.0194)$ \\
\hline Former Yugoslavia & & & & 0.0271 & & $(0.0179)$ \\
\hline Greece & & & & 0.0025 & & $(0.0315)$ \\
\hline Portugal and Spain & & & & -0.0417 & * & $(0.0242)$ \\
\hline other Western Countries & & & & 0.0740 & & $(0.0465)$ \\
\hline Eastern Europe & & & & 0.0066 & & $(0.0226)$ \\
\hline Asia & & & & -0.0228 & & $(0.0303)$ \\
\hline Spoken German (very) good & & & & 0.0150 & & $(0.0116)$ \\
\hline Spoken German missing & & & & -0.0841 & & $(0.0653)$ \\
\hline Written German (very) good & & & & 0.0301 & $* *$ & $(0.0126)$ \\
\hline Written German missing & & & & 0.1025 & & $(0.0639)$ \\
\hline German citizenship & & & & 0.0244 & & $(0.0208)$ \\
\hline Constant & 2.2157 & $* * *$ & $(0.0184)$ & 0.0919 & & $(0.0601)$ \\
\hline Observations & 39,525 & & & & & \\
\hline Persons & 6,077 & & & & & \\
\hline $\mathrm{R}^{2}$ & 0.3097 & $* * *$ & & & & \\
\hline
\end{tabular}

Note: Dependent variable log real gross hourly wage. Coefficients for immigrants refer to interactions with an immigrant indicator variable. Clustered standard errors (by person) in parentheses. $* * * / * * / *$ refer to statistical significance at the $1 \% / 5 \% / 10 \%$ level.

Source: Own calculations based on SOEP, years 1984-2009.

Table A 5: Full estimation results, low skilled

\begin{tabular}{|c|c|c|c|c|c|c|}
\hline \multirow[b]{3}{*}{ Personal characteristics } & \multicolumn{3}{|c|}{ Natives } & \multicolumn{3}{|c|}{ Immigrant Interactions } \\
\hline & \multicolumn{2}{|l|}{ Coefficient } & Standard error & \multicolumn{2}{|l|}{ Coefficient } & Standard error \\
\hline & & & & & & \\
\hline Experience/10 & 0.2523 & $* * *$ & $(0.0479)$ & -0.0213 & & $(0.0643)$ \\
\hline Experience squared/100 & -0.0738 & $* * *$ & $(0.0252)$ & -0.0054 & & $(0.0320)$ \\
\hline Experience cubic/1000 & 0.0059 & & $(0.0038)$ & 0.0036 & & $(0.0047)$ \\
\hline Tenure/10 & 0.1468 & $* * *$ & $(0.0399)$ & 0.1173 & $* *$ & $(0.0551)$ \\
\hline Tenure squared/100 & -0.0526 & $* *$ & $(0.0223)$ & -0.0855 & $* *$ & $(0.0353)$ \\
\hline Tenure cubic/1000 & 0.0091 & $* * *$ & $(0.0035)$ & 0.0147 & $* *$ & $(0.0066)$ \\
\hline $\begin{array}{l}\text { Self-employed (=1 if person is self-employed, } \\
=0 \text { otherwise) }\end{array}$ & -0.1083 & * & $(0.0558)$ & -0.0039 & & $(0.0216)$ \\
\hline Married ( $=1$ if person is married, $=0$ otherwise) & 0.0320 & $* *$ & $(0.0163)$ & 0.2230 & $* * *$ & $(0.0860)$ \\
\hline Number of children in household & 0.0148 & $* *$ & $(0.0075)$ & -0.0067 & & $(0.0087)$ \\
\hline average yearly unemployment rate & 0.0015 & & $(0.0029)$ & -0.0130 & $* * *$ & $(0.0040)$ \\
\hline \multicolumn{7}{|l|}{ Residence-Dummies } \\
\hline South Germany & 0.0126 & & $(0.0151)$ & 0.0099 & & $(0.0196)$ \\
\hline Central Germany & -Reference- & & & -Reference- & & \\
\hline North Germany & -0.0092 & & $(0.0188)$ & 0.0330 & & $(0.0287)$ \\
\hline Community $<20,000$ inhabitants & -0.0630 & $* * *$ & $(0.0175)$ & 0.0980 & $* * *$ & $(0.0338)$ \\
\hline $\begin{array}{l}\text { Community 20,000-100,000 inhabitants } \\
\text { Community }>100,000 \text { inhabitants }\end{array}$ & $\begin{array}{l}\text {-Reference- } \\
-0.0180\end{array}$ & & $(0.0157)$ & $\begin{array}{l}\text {-Reference- } \\
0.0520\end{array}$ & $* * *$ & $(0.0199)$ \\
\hline
\end{tabular}




\section{Table A 5 continued}

\begin{tabular}{|c|c|c|c|c|c|c|}
\hline \multicolumn{7}{|l|}{ Occupation } \\
\hline $\begin{array}{l}\text { ISCO1 - Legislators, senior officials and } \\
\text { managers }\end{array}$ & 0.1933 & $* * *$ & $(0.0572)$ & -0.2936 & $* * *$ & $(0.0886)$ \\
\hline ISCO2 - Professionals & 0.2174 & $* * *$ & $(0.0320)$ & -0.1997 & $* * *$ & $(0.0666)$ \\
\hline ISCO3 - Technicians and associate professionals & 0.1289 & $* * *$ & $(0.0284)$ & -0.0431 & & $(0.0414)$ \\
\hline ISCO 4 - Clerks & 0.0043 & & $(0.0268)$ & -0.0426 & & $(0.0445)$ \\
\hline $\begin{array}{l}\text { ISCO5 - Service workers and shop and market } \\
\text { sales worker }\end{array}$ & -0.0215 & & $(0.0282)$ & -0.3160 & $* * *$ & $(0.0530)$ \\
\hline ISCO6 - Skilled agricultural and fishery workers & -0.1115 & & $(0.0827)$ & 0.0592 & & $(0.1073)$ \\
\hline ISCO7 - Craft and related trades workers & -Reference- & & & -Reference- & & \\
\hline $\begin{array}{l}\text { ISCO8 - Plant and machine operators and } \\
\text { assmblers }\end{array}$ & -0.0690 & $* * *$ & $(0.0211)$ & 0.0529 & $* *$ & $(0.0240)$ \\
\hline ISCO9 - Elementary occupations & -0.1238 & $* * *$ & $(0.0253)$ & 0.0673 & $* *$ & $(0.0286)$ \\
\hline ISCO N.A. & -0.0071 & & $(0.0355)$ & -0.0227 & & $(0.0431)$ \\
\hline \multicolumn{7}{|l|}{ Industry } \\
\hline Manufactoring & -Reference- & & & -Reference- & & \\
\hline Agriculture / Fishery & -0.2338 & $* * *$ & $(0.0439)$ & 0.1363 & ** & $(0.0668)$ \\
\hline Construction & -0.0279 & & $(0.0220)$ & -0.0130 & & $(0.0266)$ \\
\hline Trade, transportation, communication & -0.1257 & $* * *$ & $(0.0221)$ & 0.0681 & ** & $(0.0296)$ \\
\hline $\begin{array}{l}\text { Credit institutions, housing, } \\
\text { business-related services }\end{array}$ & 0.0471 & & $(0.0460)$ & -0.0918 & & $(0.0633)$ \\
\hline Public administration / services & -0.0439 & $*$ & $(0.0251)$ & -0.0162 & & $(0.0375)$ \\
\hline Miscellaneous & -0.0262 & & $(0.0588)$ & -0.0062 & & $(0.0702)$ \\
\hline N.A. & -0.0887 & $* * *$ & $(0.0285)$ & 0.0490 & & $(0.0332)$ \\
\hline \multicolumn{7}{|l|}{ Immigrant-specific characteristics } \\
\hline Years since migration/10 & & & & -0.0106 & & $(0.0642)$ \\
\hline Years since migration squared/100 & & & & 0.0307 & & $(0.0295)$ \\
\hline Years since migration cubic/1000 & & & & -0.0053 & & $(0.0042)$ \\
\hline Age at migration & & & & -0.0049 & $* * *$ & $(0.0012)$ \\
\hline \multicolumn{7}{|l|}{ Immigration cohorts } \\
\hline 1973 and before & & & & -Reference- & & \\
\hline 1974-1988 & & & & 0.0556 & $* * *$ & $(0.0184)$ \\
\hline 1989 and after & & & & 0.1485 & $* * *$ & $(0.0317)$ \\
\hline \multicolumn{7}{|l|}{ Country of origin } \\
\hline Turkey & & & & -Reference- & & \\
\hline Italy & & & & -0.0447 & ** & $(0.0176)$ \\
\hline Former Yugoslavia & & & & 0.0013 & & $(0.0178)$ \\
\hline Greece & & & & -0.0031 & & $(0.0191)$ \\
\hline Portugal and Spain & & & & 0.0252 & & $(0.0197)$ \\
\hline other Western Countries & & & & 0.2679 & $* * *$ & $(0.0709)$ \\
\hline Eastern Europe & & & & -0.0482 & & $(0.0377)$ \\
\hline Asia & & & & -0.0925 & $* *$ & $(0.0440)$ \\
\hline Spoken German (very) good & & & & 0.0116 & & $(0.0102)$ \\
\hline Spoken German missing & & & & 0.0414 & & $(0.0423)$ \\
\hline Written German (very) good & & & & 0.0112 & & $(0.0127)$ \\
\hline Written German missing & & & & -0.0224 & & $(0.0393)$ \\
\hline German citizenship & & & & 0.0084 & & $(0.0322)$ \\
\hline Constant & 2.2270 & $* * *$ & $(0.0321)$ & 0.0355 & & $(0.0691)$ \\
\hline Observations & 13,490 & & & & & \\
\hline Persons & 2,134 & & & & & \\
\hline $\mathrm{R}^{2}$ & 0.3572 & $* * *$ & & & & \\
\hline
\end{tabular}

Note: Dependent variable log real gross hourly wage. Coefficients for immigrants refer to interactions with an immigrant indicator variable. Clustered standard errors (by person) in parentheses. $* * * / * * / *$ refer to statistical significance at the $1 \% / 5 \% / 10 \%$ level. Source: Own calculations based on SOEP, years 1984-2009. 
Figure A 1: Predicted experience earnings profiles, highly skilled individuals

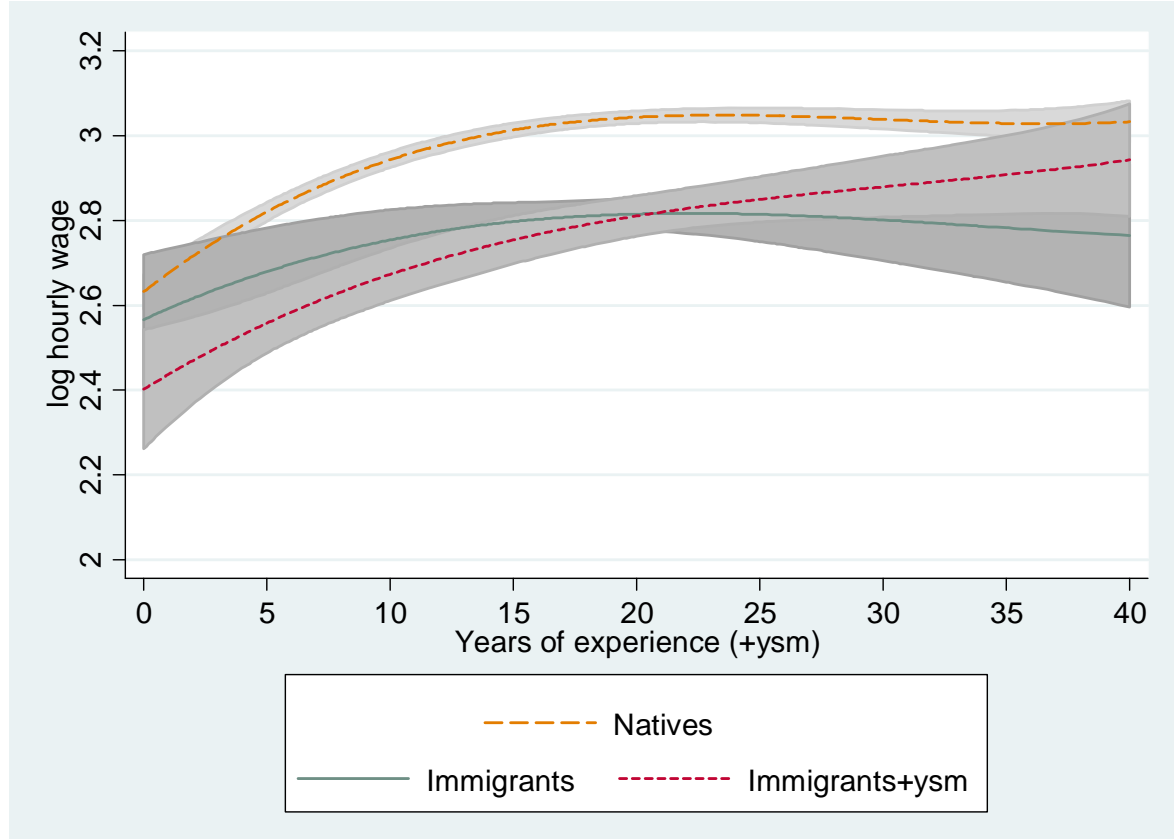

Note: Personal characteristics for highly skilled immigrants and natives were set to their respective means. "Immigrants+ysm" refers to the predicted log hourly wage of immigrants for whom experience and ysm go hand in hand, i.e., all experience is acquired in Germany as soon as the immigrant arrives. See Table 4 for details. The shaded areas represent $95 \%$ confidence intervals.

Source: Own calculations based on SOEP, years 1984-2009.

Figure A 2: Marginal effect of experience and experience + ysm, highly skilled individuals

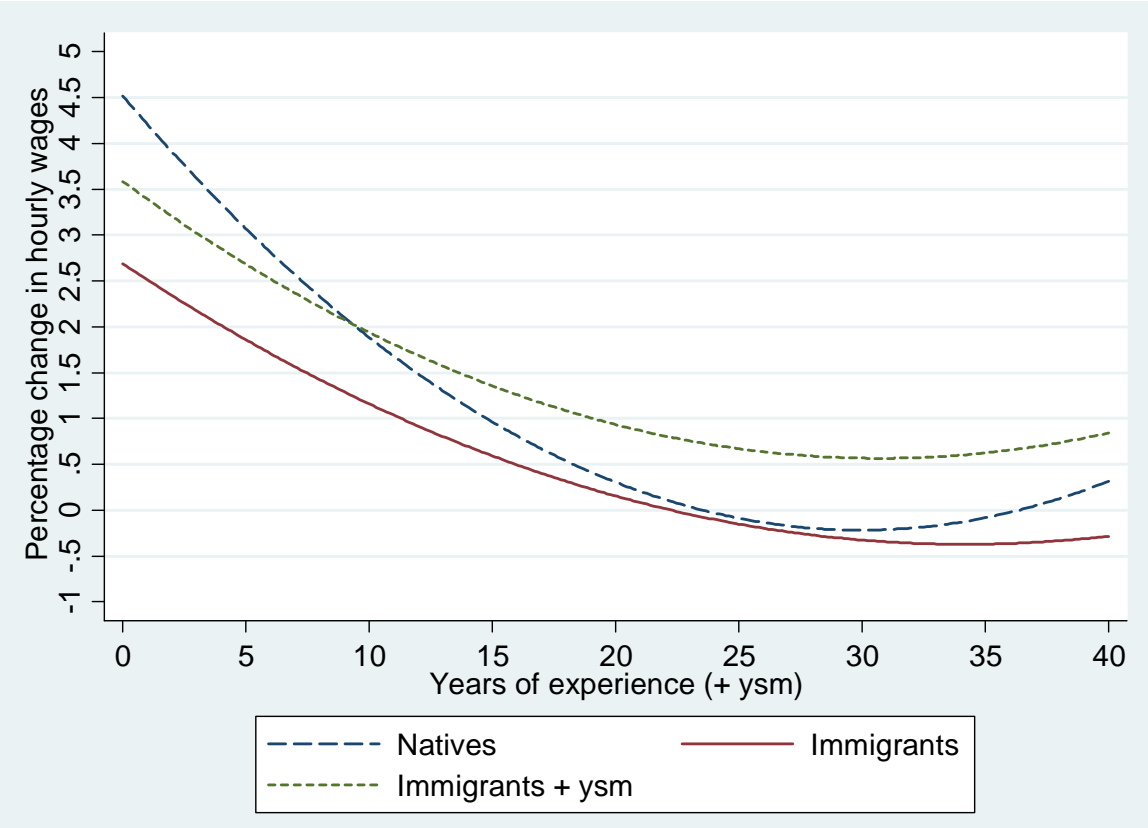

Source: Own calculations based on SOEP, years 1984-2009. Results based on Table 4. 
Figure A 3: Predicted experience earnings profiles, medium skilled individuals

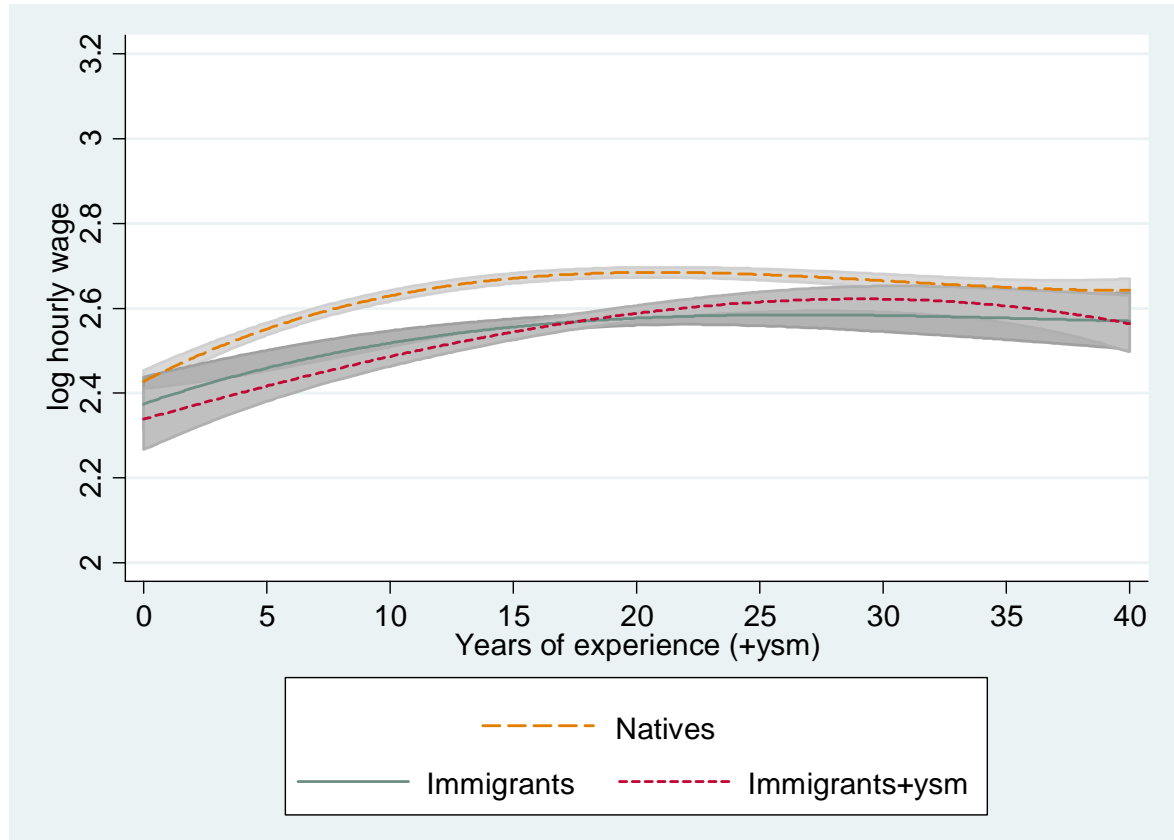

Note: Personal characteristics for medium skilled immigrants and natives were set to their respective means. "Immigrants+ysm" refers to the predicted log hourly wage of immigrants for whom experience and ysm go hand in hand, i.e., all experience is acquired in Germany as soon as the immigrant arrives. See Table 4 for details. The shaded areas represent $95 \%$ confidence intervals.

Source: Own calculations based on SOEP, years 1984-2009.

Figure A 4: Marginal effect of experience and experience + ysm, medium skilled individuals

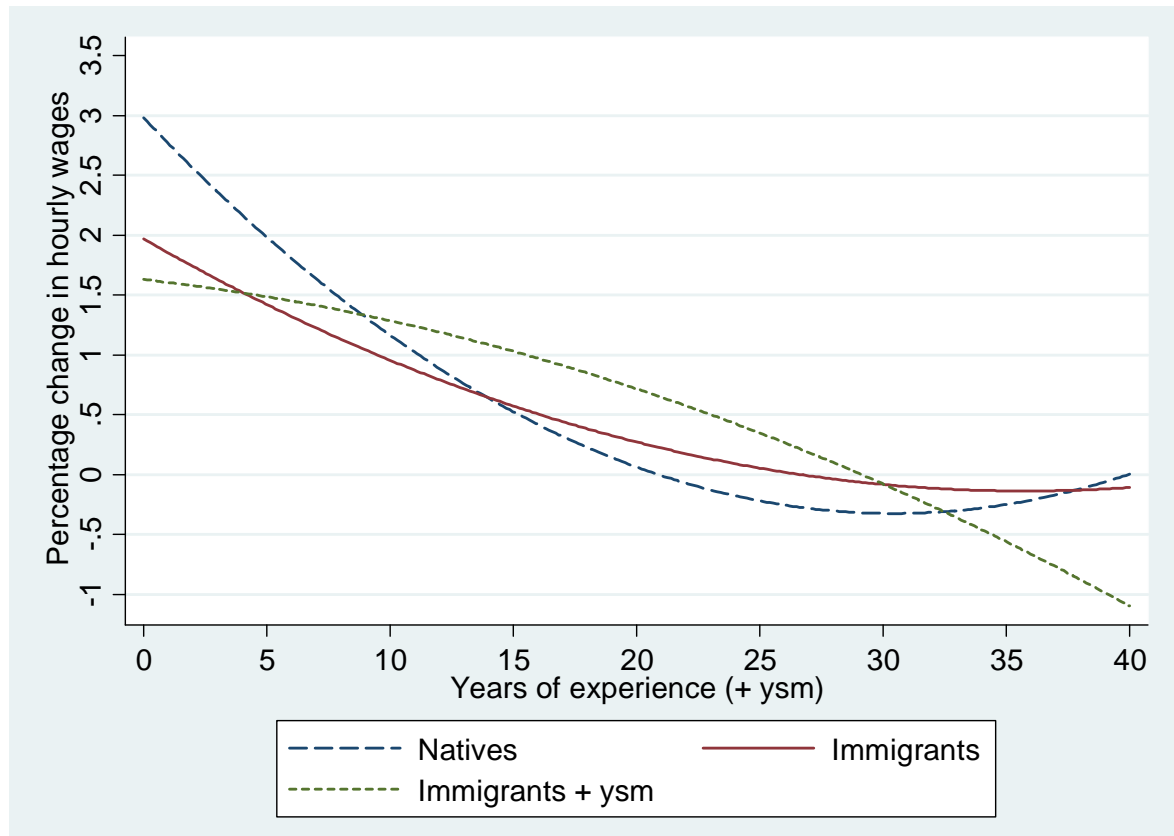

Source: Own calculations based on SOEP, years 1984-2009. Results based on Table 4. 
Figure A 5: Predicted experience earnings profiles, low skilled individuals

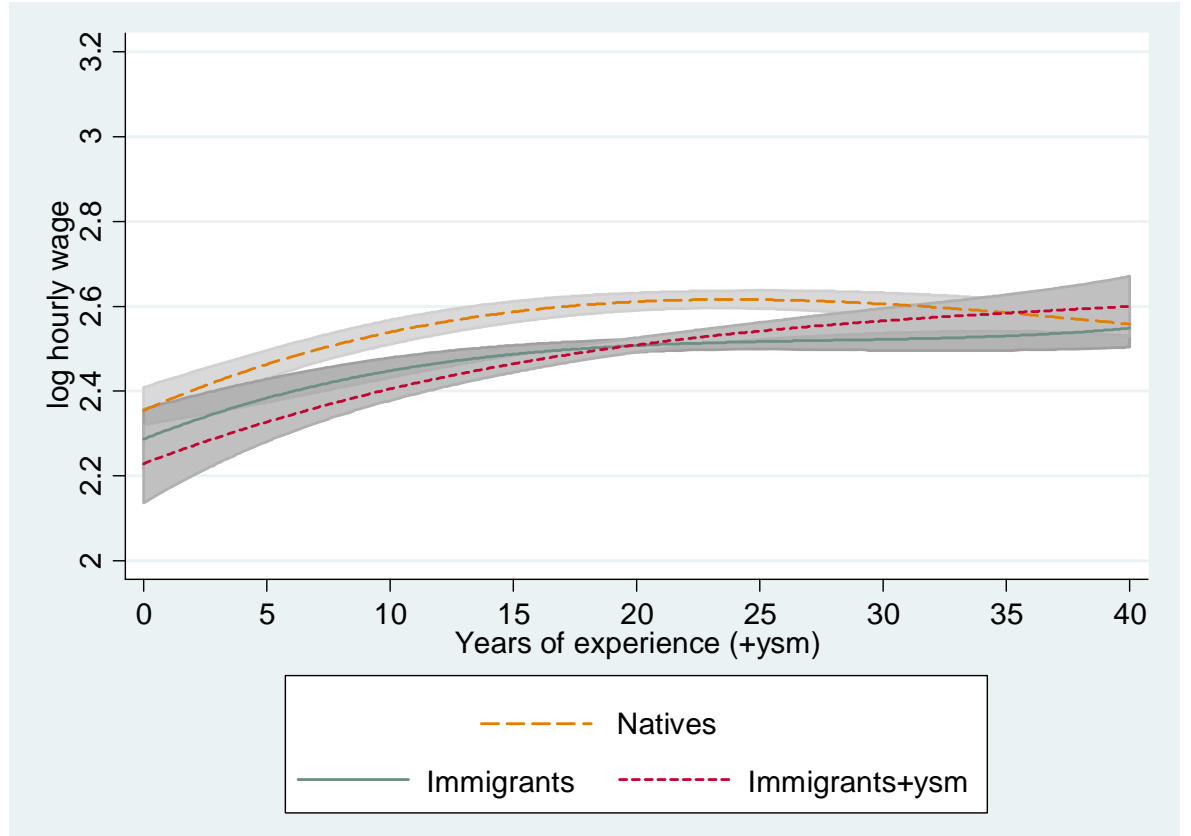

Note: Personal characteristics for low skilled immigrants and natives were set to their respective means. "Immigrants+ysm" refers to the predicted log hourly wage of immigrants for whom experience and ysm go hand in hand, i.e., all experience is acquired in Germany as soon as the immigrant arrives. See Table 4 for details. The shaded areas represent $95 \%$ confidence intervals.

Source: Own calculations based on SOEP, years 1984-2009.

Figure A 6: Marginal effect of experience and experience + ysm, low skilled individuals

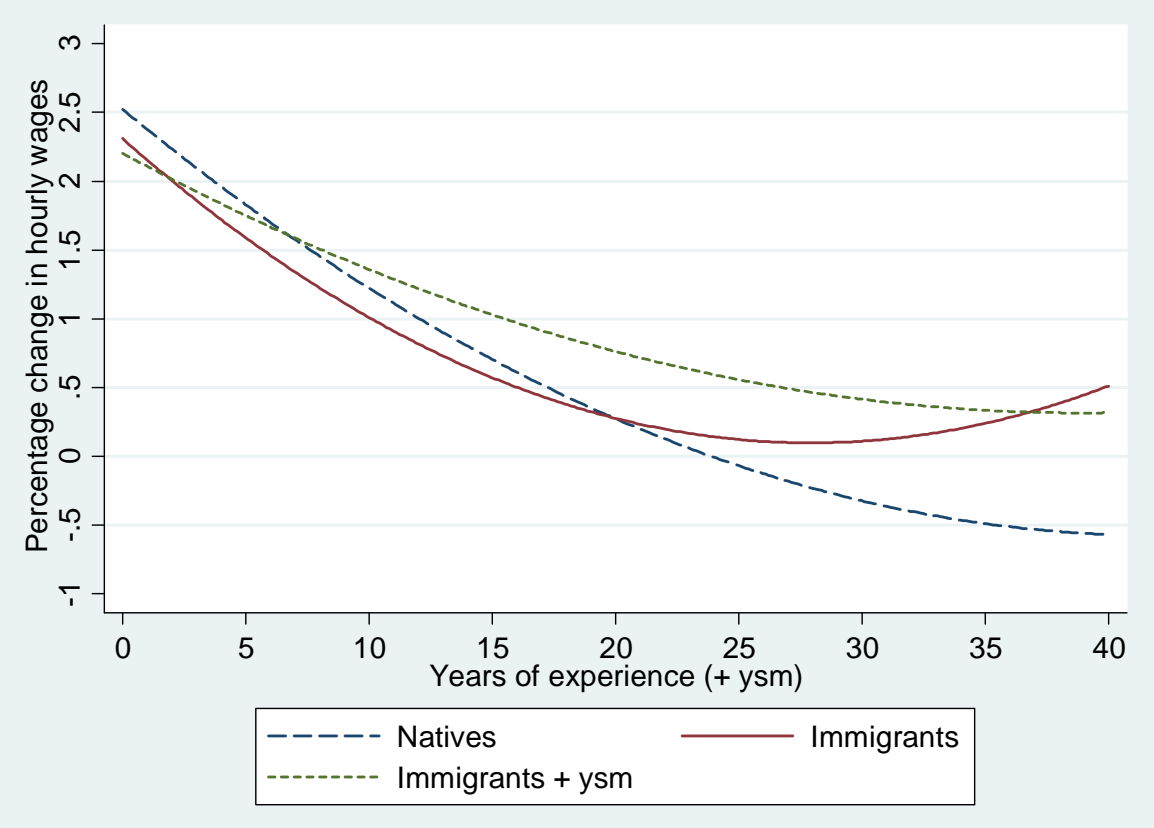

Source: Own calculations based on SOEP, years 1984-2009. Results based on Table 4. 